\title{
Administration of Three Natural Products as Protective Agents Against The Genotoxic And Cytotoxic Effect of Methotrexate in Mice (Mus Musculus). Zowail, M.E.M.; Awwad, M.H.; Khater, E.H. and Nafie, Ebtesam. H.O. Zoology department, Faculty of science, Benha University, Egypt
}

\begin{abstract}
Background: Methotrexate is an antimetabolite and antifolate drug. It is used in treatment of cancer, autoimmune diseases.

Material and methods: 210 healthy adult male Swiss albino mice (Mus musculus), were allotted among three groups. The animal were given daily $(\mathbf{0 . 0 6 5} \mathbf{m g} / \mathbf{m l})$ of methotrexate intraperitonealy followed by injection of Omega-3 plus at dose $(8.58 \mathrm{mg} / 20 \mathrm{~g}$ mice $)$, Apple at dose (1.43 $\mathbf{~ m g} / 20 \mathrm{~g}$ mice) and Psyllium at dose (18.2mg / $20 \mathrm{~g}$ mice) for five days.

Results: Various Structural and numerical chromosomal aberrations in bone marrow cells; mitotic activity and sperm head abnormality were recorded, quantitated, and statistically analyzed. Also DNA extraction and apoptosis detection in liver was done. The intensity of apoptotic bands located at $200 \mathrm{~b}$ p; $400 \mathrm{~b}$ p ; $600 \mathrm{~b}$ p;800 b p and intact DNA measured by software Gel Pro program as maximum optical density values.

Conclusion:, Methotrexate had adverse effect on chromosomal and sperm head structure, also it induce apoptosis, necrosis and decrease total DNA in mice liver.Omega-3 plus, Apple, and Psyllium attenuate the methotrexate-related toxic effects.
\end{abstract}

Key words: Methotrexate - Omega-3 plus- Apple- Psyllium-chromosomal aberrations- sperm- DNAliver.

\section{Introduction}

Methotrexate (MTX) is known as amethopterin. It is an antimetabolite and antifolate drug. Methotrexate (MTX), an antineoplastic drug, which is widely prescribed for the treatment of acute lymphoblastic leukaemia, non-Hodgkin's lymphoma, various types of sarcomas, carcinomas, breast and testicular cancers [1]. The drug was developed by Yellapragada Subbarao.

Patients with cancer take numerous alternative products to protect themselves from cancer. The review article of Muriel [2] provides information about 47 herbs and natural products that have the potential to protect humans against cancer. The majority of these herbs and natural products are fruits, vegetables, animal or fish products, grains, and molecular components of plants or herbs that are found in human diets. Several grains such as barley, rice bran, and wheat bran protect against cancer. Various vegetables, fruits, and plants also show promise as protection against cancer: apple, asparagus, 
blueberry, cabbage, cranberry, green tea, lavender tea, olive oil, peanut oil, and spinach [2].

Omega-3 Plus is composed of 1000gm Fish oil (EPA/ DHA 30\%) and $100 \mathrm{gm}$ wheat germ oil. Fish oil have scientific names of N-3 fatty acid, N-3polyunsaturated fatty acids and others. Salmon, Albacore, Tuna and Mackerel are just a few of the fish with high concentrations of omega three in their system. These fatty acids seem to decrease rates of prostate cancer [3] and prolong cancer remissions [4], also found that fish oils decrease production of lactic acid in tumor cells.

Wheat germ oil Obtained from the embryo or kernel of the wheat grain, wheat germ oil is a light yellow, fat soluble natural oil. The germ is the most nutritious portion of the wheat and it makes up about $2.5 \%$ of the weight. Wheat germ oil also contains alpha- and gammatocotrienols $[\mathbf{5 , 6}]$

Wheat germ oil Protects material in the cell nucleus and DNA from damaging free radicals. Studies have shown that vitamin $\mathrm{E}$ protects guanosine amino acid, which is a component of DNA, from damaged by hydroxyl and superoxide radicals. On the other hand, it destroys peroxynitrite, which is a substance similar to the nitrogen dioxide compounds present in cigarette smoke. Wheat germ oil not only prevents autoxidation of unsaturated fatty acids but also generates DNA protective properties [7].
Apple has a scientific name of Malus sylvestris. Individuals use apples for many conditions from cleaning their teeth to treating diarrhea, constipation, fever, and cancer. The antioxidant flavonoid quercetin in apples seems to have a protective property against lung cancer. Apple's antioxidant power is not simply due to its content of Vitamin C. In fact, the vitamin $\mathrm{C}$ content of apples contributes just $0.4 \%$ to their total antioxidant activity [8]. Fresh apples have been reported to suppress mammary carcinogenesis and proliferative activity and induce apoptosis (programmed cell death) in mammary tumours in rats [9].

Psyllium is a herbaceous low-growing annual plant native to India and Iran, and is also referred to as Ispaghul [10]. The seed husks of this plant, Plantago ovata, are commonly referred to as ispaghula husks [11] or psyllium [12]. Psyllium husk is a gel-forming, watersoluble fiber [13]. Psyllium is an effective blood cholesterol-lowering agent in human studies [14]. Adding high fiber foods (such as psyllium enriched cereals) to your diet may help lower heart disease risk. In fact, studies show that a diet high in water soluble fiber is associated with lower triglyceride levels, and a lower risk of cardiovascular disease [15]. Psyllium, may have a protective role for helping lower blood pressure, by adding fiber (12 $\mathrm{g}$ of soluble fiber per day) in diet [15].

The aim of the present work is to investigate the side effect of Methotrexate on chromosomes and sperms head morphology by cytogenetic 
methods. Also, detection of its side effect on DNA in liver by method of molecular biology and the protective role of Omega -3Plus, Apple and Psyllium against Methotrexate effects.

\section{MATERIAL AND METHODS}

In this study 210 healthy adult male Swiss albino mice (Mus musculus), approximately three months old and weighting $( \pm 20 \mathrm{~g})$ were used in the present study. These mices were obtained from the National Research Center in Dukki, Cairo (N.R.C).The animals were kept in individual special rodents cages in the laboratory under constant condition of temperature (25 \pm $3^{\circ} \mathrm{C}$ ) with a reveres natural dark - light cycle 12 / 12 hrs. Animals were maintained on a standard rodent diet, obtained from Egyptian company of Oils and Soap Kafr-Elzayat Egypt, manufactured especially for laboratory purposes. The diet composed of $20 \%$ casein, $15 \%$ corn oil, $55 \%$ corn starch 5\% salt mixture and 5\% vitaminized starch. Water was available ad libitum.

Maintenance of animals and experimental procedures was approved by the animal ethical committee in accordance with the guide for care and use of laboratory animals of BenhaUniversity, Egypt. Methotrexate is available as Methotrexate Mylan $50 \mathrm{mg} / 2 \mathrm{ml}$, solution for injection was produced by Haupt phrma GmbH, France. Methotrexate was injected intraperitonealy at dose level $0.065 \mathrm{mg} / \mathrm{ml}$ calculated according to Paget and Barnes [16] daily for 5 days.

Apple available as Apple-lite tablets, each tablet contains; $500 \mathrm{mg}$ of apple fibers (apple cuticle) and $50 \mathrm{mg}$ of pure apple gel pectin (from apple pulp), produced by Arab Co. for pharmaceuticals\& Medicinal plants (MEPACOMEDIFOOD) Enshas El Raml-Shakeya, Egypt. The tablet was ground and dissolved in $100 \mathrm{ml}$ distilled water. It is used as a dose level of $\mathbf{( 1 . 4 3}$ $\mathbf{m g} / 20$ g mice) modified according to therapeutic dose of human [16] and each animal was injected intraperiotenally $0.26 \mathrm{ml}$ daily for 5 days.

Omega-3-plus available as soft gelatin capsules, each capsule contains; 1000 mg Fish Oil and 100mg wheat germ oil.Omega-3-plus produced by South Egypt Drug industries Co.(SEDICO),6 October City, Egypt. It is used as a dose level of $(\mathbf{8 . 5 8} \mathbf{~ m g} / \mathbf{2 0} \mathbf{g}$ mice) modified according to therapeutic dose of human [16] and each animal was injected intraperiotenally 0.1 $\mathrm{ml}$ daily for 5 days.

Psyllium available as Regumucil Powder, each 100 gm contains 49gm psyllium husk powder, produced by Kahira Pharm.\&Chem.Ind.Co.for multipharma, Egypt. Each package contains 7 gm regumucil powder, dissolved in $250 \mathrm{ml}$ distilled water. It is used as dose level (18.2mg /20 g mice) modified according to therapeutic dose of human [16] and each animal was injected intraperitonally 0.65 daily for 5 days.

The animals divided into three groups, group A, B and C; each group contains 70 male mice. Group A used to study chromosomal abnormalities. Group B used to study sperm head morphology by classical methods of 
cytogenetic, while group C contain 60 male mices used to molecular studies. Each group divided into 12 sub group, 5 mices were allotted to each sub group.

Sub group (1): Control Group: - 5 mices were injected intraperitoneally with $0.9 \%$ sterile saline solution. Sub group (2): Methotrexate Group: - 5 mices were injected intraperitoneally with methotrexate at dose $(\mathbf{0} \mathbf{. 0 6 5} \mathbf{m g} / \mathbf{m l})$ daily for 5 days. Sub group (3): Omega-3-plus Group: - 5 mices were injected intraperitoneally with Omega-3-plus at dose $(\mathbf{8 . 5 8} \mathbf{~ m g} / \mathbf{2 0 g}$ mice) daily for 5 days.Sub group (4): Apple Group: - 5 mices were injected intraperitoneally with Apple-lite at dose $(1.43 \mathrm{mg} / \mathbf{2 0 g}$ mice $)$ daily for 5 days. Sub group (5): Psyllium Group: - 5 mices were injected intraperitoneally with Regumucil at dose (18.2mg/20g mice) daily for 5 days.Sub group (6): (MTX+Omega) Group:5 mices were injected intraperitoneally with Methotrexate and omega-3-plus at dose ((0 $.065 \mathrm{mg} / \mathrm{ml})+(8.58 \mathrm{mg} / 20 \mathrm{~g}$ mice $)$, respectively $)$ daily for 5 days. Sub group (7): (MTX+Apple) Group: - 5 mices were injected intraperitoneally with Methotrexate and Apple at dose ((0 $.065 \mathrm{mg} / \mathrm{ml})+(1.43 \mathrm{mg} / 20 \mathrm{~g}$ mice $)$, respectively) daily for 5 days. Sub group (8): (MTX+Psyllium) Group:-5 mices were injected intraperitoneally with Methotrexate and Psyllium at dose $((\mathbf{0} . \mathbf{0 6 5} \mathrm{mg} / \mathrm{ml})+(\mathbf{1 8 . 2} \mathrm{mg} / \mathbf{2 0 g}$ mice), respectively) daily for 5 days. Sub group (9): (MTX after omega) Group:- 5 mices were injected intraperitoneally with omega-3-plus followed by Methotrexate at $\operatorname{dose}((\mathbf{8 . 5 8} \mathbf{~ m g} / \mathbf{2 0 g}$ mice) then $(0.065 \mathrm{mg} / \mathrm{ml})$, respectively) daily for 5 days. Sub group (10): (MTX after Apple) Group:-5 mices were injected intraperitoneally with Apple followed by Methotrexate at dose $((1.43 \mathrm{mg} / 20 \mathrm{~g}$ mice $)$ then $(0 \quad .065 \mathrm{mg} / \mathrm{ml})$, respectively) daily for 5 days.Sub group (11): (MTX after Psyllium) Group: - 5 mices were injected intraperitoneally with psyllium followed by Methotrexate at dose ((18.2mg/20g mice) then $(0.065 \mathrm{mg} / \mathrm{ml})$, respectively) daily for 5 days.Sub group (12): ( MTX before Omega) Group: - 5 mices were injected intraperitoneally with Methotrexate followed by Omega -3-Plus

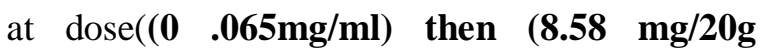
mice), respectively) daily for 5 days.Sub group (13): (MTX before Apple) Group:-5 mices were injected intraperitoneally with Methotrexate followed by Apple at dose ((0 $.065 \mathrm{mg} / \mathrm{ml})$ then $(1.43 \mathrm{mg} / 20 \mathrm{~g}$ mice $)$, respectively) daily for 5 days.Sub group (14): (MTX before Psyllium) Group:-5 mices were injected intraperitoneally with Methotrexate followed by Psyllium at dose $((\mathbf{0} \mathbf{. 0 6 5} \mathrm{mg} / \mathbf{m l})$

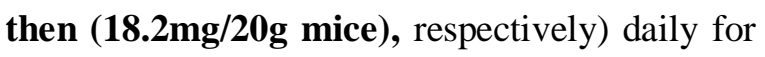
5 days.

Metaphase spreads were prepared according to Yosida and Amano [17]. Fifty well metaphase spreads were examined / each animal. The type and frequency of chromosomal aberrations were recorded and photographed. Mitotic activity of the cells was calculated as the number of dividing cells including prophase and metaphase 
per 1000 cells. Cells with stickiness were considered as dividing cells.

Smears for sperm morphology were prepared and stained with eosin according to Mukherjee, et al [18]. One thousand sperms were counted for each animal, and the abnormal shape involving the head was recorded.

Statistical analysis was carried out using the student (t) test [19].

DNA extraction and apoptosis detection in tissues (liver) was done according to" salting out extraction [20] and modification [21]. DNA damage was detected in lysate tissue [22]. Gel was prepared using $1.8 \%$ electrophoretic grade agarose. All the gels of DNA were photographed with digital camera while the DNA were visualized at a312 nm UV light under a transilluminator.

\section{RESULTS}

various chromosomal aberrations were observed in the bone marrow cells of male mice treated with Methotrexate and protected with Omega-3 plus, Apple or psyllium. Both Structural and numerical types of aberrations and chromosomal stickiness were recorded.

The Structural aberrations included chromatid deletion (Fig.1a), fragmentation (Fig.1b), centromeric attenuation (Fig.1c), Centric fusion (Fig.1d), Ring (Fig.1e), end to end association (Fig.1f), break (Fig.1g) and gap (Fig.1h).The numerical aberrations included monosomy, trisomy and polyploidy(Fig.1i). Stickiness may give arise to sticky adhesions between two or more chromosomes, and formation of sticky bridges at metaphase (Fig. 1j).

Table (1), fig. (2) showed the average of chromosomal abnormalities of bone marrow cells of mices treated with Methotrexate and protected with Omega-3plus, Apple and psyllium. It represented a very high significant increase in treated group with methotrexate (141.40 \pm 17.76) than control group (7.40 \pm 6.28$)$, on the other hand it indicated that omega-3 plus made a high protective role against Methotrexate especially when injected with methotrexate $\mathbf{( 4 0 . 2}$ \pm 9.97) or when injected after administration of methotrexate $(\mathbf{2 7 . 8} \pm \mathbf{1 2 . 0 2})$. As well as, administration of Apple, and Psyllium with MTX showed a protective effect, when compared with animal groups treated with MTX only. The result indicated that pre-treatment with Apple and Psyllium is more protective than posttreatment. Marked decrease in mean values of structural chromosome aberrations in bone marrow cells $(27.40 \pm \mathbf{1 1 . 9 7})$ and $(\mathbf{3 6 . 8} \pm \mathbf{1 1 . 8 3})$ when injected with apple and psyllium respectively before methotrexate.Data represented a considerable increase in average of numerical aberration of chromosomes when animals treated with Methotrexate by (21.6 \pm 4.30) in comparison with control. Omega -3-plus exhibited a noticeable reduction of the mean values of numerical aberration appeared in animal groups administrated with Omega-3- plus and its effect is the greatest especially before the anticancer drug administration. On the other side, the Apple and Psyllium revealed a sharp 
decline in numerical aberration of chromosomes when treated with anticancer drug. Moreover, the Apple exhibited a great role to repair the aberration in mice bone marrow cells especially when administrated before methotrexate. [Table (2) fig. (3)].

There were a very highly significant reduction in the mitotic index in group injected with MTX in compare with control group. These results indicated that treatment with methotrexate reduced the mean values of mitotic index in compare with control group. While the three natural products (Apple, Omega-3-plus and Psyllium) repair a decrease in mitotic index caused by MTX.

Table (3), fig. (5) represented the incidence of abnormality in the shape of sperms per 1000 for each mice treated with methotrexate and protected with Omega-3-plus, Apple or psyllium, which include without hook shape (fig. 4a), banana shape (fig.4b) and amorphous shape (fig.4c).Methotrexate group showed a very high significance increase in the average of total abnormality compared with control group. The highest incidence of abnormality in the shape of sperms of mices treated with methotrexate was amorphous while without hook shape was the lowest frequency. On the other hand, the three natural products showing a protective effect when administrated with, after and before methotrexate. Omega-3-plus is the best protective natural product when administrated before anticancer drugs. Damage and optical density of DNA in mices treated with
Methotrexate and protected with Omega-3-plus, Apple and Psyllium were observed in liver (Fig. 6\& 7 and table 4), it represents that: Damage in DNA of mices treated with methotrexate was observed when compared with control so the optical density of apoptotic bands of DNA at 200; 400; 600 and 800 bp showed a very significant increase than control. On the other hand, intact DNA decreased sharply than control. The obtained results showed that the natural products (Omeg-3 plus, Apple, and Psyllium) reduce DNA damage induced by Methotrexate.

Table $(5,6,7)$ showing the optical density of intact and apoptic fragments of DNA at 200, 400, 600, $800 \mathrm{bp}$ in liver of mices treated with Methotrexate and the natural products together; Methotrexate after natural products and Methotrexate before natural products. It is clear that the intact DNA increase sharply in the liver of mices treated with Methotrexate and the natural products ( Omega-3 plus; Apple and Psyllium) together than the mices treated with just methotrexate as demonstrated in figure ( 8 and 9). Besides, there is a protection action of natural products when treated after and before Methorexate as shown in figure $(10,11,12,13)$. There is a great protection action of Apple and psyllium when mices injected with Methotrexate after Apple or Psyllium. On the other hand, Omega- 3 plus has the best protection action when mices treated with Methotrexate before Omega-3 plus. 


\section{Discussion}

The present study aimed to investigate the side effects of Methotrexate as anticancer drug on the chromosomes; sperm head abnormalities and the DNA damage in male mice (Mus Musculus), and protection by Omega-3Plus, Apple and Psyllium.

In the present study, Methotrexate was target because it is used as an antitumor drug used for treatment of various kinds of cancer [23].At the same time, using Methotrexate in cancer chemotherapy has various side effects, including vomiting, diarrhea, mucositis, and decrease of nutrient absorption [24]. The toxic effects are not considered to be a result of direct action on the gastrointestinal tract tissues but rather to be the consequence of an inhibition in dihydrofolate reductase synthesis [25]. It affects not only tumor cells but also rapidly dividing host cells such as crypt cells of the gastrointestinal mucosa. It is characterized histologically by villus atrophy or crypt loss [26].Methotrexate is under class of Antimetabolites drugs that interfere with DNA and RNA growth by substituting for the normal building blocks of RNA and DNA. These agents damage cells during the S phase[27].

The use of plants for the prevention of diseases is an ancient practice. Recently, there is a direction to use plants, herbs, composition of fruits, vegetables and grains in medicinal manufactures for their medicinal and protection abilities against many illnesses especially in case of cancer patients. Lifestyle and especially diet can also serve as important sources of antioxidants. In vitro studies demonstrated that certain micronutrients may reduce DNA oxidation [28] as well as mutagenicity as [29].

The aim of the present study using three different natural products as a try to minimize the side effects in patients undergoing chemotherapy. In the present study we used Omega -3 Plus, Apple and Psyllium as trials testing the effectiveness of antioxidants as cancer prevention agents.

The fatty acids of fish oil seem to decrease rates of prostate cancer [3].The omega-3 fatty acids in fish oil seem to be able to expand blood vessels, and this brings blood pressure down [30, 31]. Wheat germ oil obtained from the embryo or kernel of the wheat grain. Wheat germ is a rich source of B complex vitamins, with wheat germ oil being the richest source of tocopherols [32, 33].

The second natural product that we used in the present study is Apple.Apples are a rich source of nutrient as well as non-nutrient components and contain high levels of polyphenols and other phytochemicals [34]. There is some evidence for effects of flavonoid intake on reduced risk of lung cancer in some populations [35].

Psyllium as kind of prebiotics was associated with a reduced incidence of colon cancer in various populations [36]. Prebiotics have been shown to deactivate genotoxic carcinogens. DNA damage had been prevented and 
chemopreventive systems may be stimulated in vivo in colon tissues [37].

In the present study, the increases in chromosomal aberrations were observed in the male Mus musculus (significant and highly significant difference) after treatment with Methotrexate. These aberrations are structural (include deletion, fragmentation, centric fusion, chromatid break, centromeric attenuation, gape, end to end association and stickiness) and numerical (included monosomy, trisomy and polyploidy). Mitotic index also affected after treatment with methotrexate.

It is obvious from the present study that the statistical analysis of chromosomal fragmentation, deletion, break, gap and stickiness of chromosomes of bone marrow cells of mices treated with methotrexate showed a very highly significant increase in comparison with control. These results agreed with Mondello et al.[38] who analyzed the effect of Methotrexate on chromosome morphology in cultured lymphocytes, and a high percentage of aberrant mitoses was found that; chromosome aberrations, such as gaps and breaks on all the chromosomes, but are preferentially located on chromosome n.3 at band p14. When the cells were continuously exposed to the Methotrexate, the chromosome damage appeared to be particularly severe. Also Choudhury et al. [39] results agreed with our result as they investigated cytogenetic toxicity of methotrexate in mouse bone marrow. They studied chromosomal aberrations and mitotic index at 24-h post-treatment and micronucleus (MN) test at 30 -h post-treatment. The induction of statistically significant number of chromosomal aberrations, percentage of aberrant metaphases and highly significant number of MN per thousand polychromatic erythrocytes by all the doses of MTX indicated that it has highly clastogenic effect. Significantly increased of gap was observed in this study in treated animals with methotrexate in comparison with control and this was due to the local loss of both DNA and chromosomal basic protein, this loss occur on a chromatid in the locus and doesn't represent real discontinuities in the chromosome [40]. It was occurred as a result of primary lesions which disrepair to give aberrations [41].

In the present study the numerical aberrations showed a significant difference in group treated with methotrexate in comparison with control. Our data represented considerable increase in monosomy, trisomy and polyploidy of chromosomes in groups injected with methotrexate. Aneuploidy in general arise as a non disjunction of homologous chromosomes at meiosis, or by non disjunction of sister chromatids at mitosis. The failure of disjoin or separate accurately can occur at any nuclear division in which the event occurs at the time occurrence. Non disjunction at meiosis gives rise to gametes with one more or less chromosome than usual. If such gametes are viable and fuse to produce a zygote, the zygote will be trisomic or monosomic for non disjunction chromosomes [42]. 
The value of chromosome stickiness increased in bone marrow cells of mices treated with methotrexate than control. Stickiness is due to the process of depolymerization of DNA, thus making the chromosome surface becoming sticky. Stickiness has been regarded later as physiological and unspecific disturbance attributed to the action of proteins on chromosome or form improper folding of the chromosome fibers into chromatids and thus chromosome become attached to each other by means of sub chromatid bridges [43].

The mean values of mitotic index decreased in mices after treated with methotrexate. Mitotic index is a measure for the proliferation status of a cell population. The apparent lower values for mitotic index reported in the present study may be due to decrease in cell number arrested in metaphase [44].

The results of the present study showed that Methotrexate induced genotoxic effects including DNA damage (apoptosis and necrosis) in the treated mices. Our result agreed with Martin et al. [45] who observed that Methotrexate induces oxidative DNA damage and is selectively lethal to tumour cells with defects in the DNA mismatch repair gene MSH2. Genotoxic mechanism of Methotrexate was explained by Frouin et al. [46] who explained that Methotrexate exert their antiproliferative activity through the inhibition of dihydrofolate reductase and, as a consequence, of thymidylate synthesis, there by inducing nucleotide misincorporation and impairment of DNA synthesis. As well as investigated a clear signs of apoptosis such as nuclear shrinkage, chromatin condensation and degradation.Remarkably, cell viability was lower and the apoptotic process was triggered more efficiently in the cells [46].

According to Ddhania et al. [47] who investigated that MTX-induced intestinal toxicity was evaluated at the dose of $2.5 \mathrm{mg} / \mathrm{kg}$ for short-term (5 days treatment) and $1 \mathrm{mg} / \mathrm{kg}$ for long-term (5 days in a week for four consecutive weeks treatment) study. They added that MTX treatment induced diarrhoea and mortality in rats, which indicating its severe toxicity in the target organ of investigation, i.e., intestine. Further, the intestinal toxicity of MTX was assessed by evaluating different parameters of oxidative stress, DNA damage, cytotoxicity as well as histological changes. Apoptosis is generally considered as an energy-dependent process that requires active participation of many proteins and other cellular macromolecules. Apoptosis seems to be induced by mild genotoxic stimuli; the strength of stimuli increases the cell death mode shifting it towards necrosis. This seems to be due to the fact that most the intense genotoxic stimuli damage the proteins or genes that make these proteins and other cellular macromolecules which may be required for apoptosis [48]. Apoptosis is mediated by members of the caspase family of proteases, and eventually causes the degradation of chromosomal DNA. 
In the present study Omega-3 Plus acts as highly protective agent so aberrations decreased in all protected groups. As well as the result showed the best and very highly significant protective effect of Omega-3- Plus before Methotrexate drug administration than after administration of both anticancer drugs.

Hong et al. [49] who observed the protective effect of fish oil against oxidatively induced colon cancer. Whereas their study confirmed that fish oil protects against colon cancer by decreasing oxidative DNA damage at the initiation stage of colon tumorigenesis, oxidative DNA damage, proliferation, and apoptosis. On the other hand, Manna et al. [50] reported that Fish oil regulates cell proliferation, protect DNA damages and decrease HER-2/neu and c-Myc protein expression in rat mammary carcinogenesis.

Our Data indicated that Apple with MTX showing a protective effect, when compared with animal groups treated with just MTX only. As well as, the results indicated that the protective effect of Apple after MTX is more useful than before.

These result agreed with Liu et al. [51] who indicated that, Apples are one of the very few individual foods specifically identified in population studies as having the capacity to reduce cancer risk and more specifically lung cancer. Besides, Adhami et al.[52], stated that Fisetin which is commonly found in many fruits and vegetables such as apples, is more effective against melanoma and cancers of the prostate, pancreas and the lungs.

There is a significant decrease in the chromosome aberration and DNA damage due to protective effect of Psyllium in our data. Moreover, the protective effect of psyllium was the best when Psyllium was given after MTX and is more useful than pre-treatment.

These result agreed with Segal et al. [36] who explained that Psyllium as kind of prebiotics was associated with a reduced incidence of colon cancer in various populations . As well as Cui et al. [53] indicated that whole-grain intake is protective against cancer, cardiovascular disease, diabetes and obesity.

Three types of sperm head abnormalities were recorded. Amorphous, banana like and without hook shape. Amorphous and banana like were the highest incidence of aberration in groups treated with Methorexate, while banana shape was the lowest frequency. On the other hand, the three natural products which used in the experiment (Omega -3 plus, Apple and Psyllium) showing a protective effect in the mean values of the sperm head abnormalities of animals Mus musculus. These result agreed with Choudhury et al. [54] who investigated that cytogenetic toxic effects of methotrexate, a widely prescribed antineoplastic drug, in the male germline cells of Swiss mice, was highly clastogenic to the spermatogonial cells at 24-h post-treatment after a single intraperitoneal exposure. 
Methotrexate-induced cytotoxicity and genotoxicity in germ cells of mice indicated by Padmanabhan et al. [55]. As they observed the cytotoxic effect of MTX as sperm head abnormalities, seminiferous tubule damage, sperm DNA damage. As well as, they observed that MTX treatment showed a significantly reduction in the sperm count and increased the occurrence of sperm head abnormalities in a dose dependent manner. It induced the testicular toxicity as evident from the histology of testis. As well as Morris et al. [56] observed the significance of impaired spermatogenesis in a young man undergoing methotrexate treatment for severe psoriasis with associated arthritis.

In an attempt to explain the different mechanisms involved in the induction of the abnormal morphology of the sperm heads, Kaczmarski [57] stated that incomplete condensation of chromatin and the presence of large vacuoles and canals containing remnants of cytoplasm in various regions of the head is the cause of failure of sperm to pass through the final steps of maturations occurring normally during spermatogenesis. Moreover, Topham [58] mentioned the agents which accumulate in the testis can cause alterations in testicular DNA and disrupt the process of differentiation of spermatozoa directly.

\section{REFERENCES}

[1] Jolivet J, Cowan KH, Curt GA, Clendeninn NJ and Chabner BA (1983): The pharmacology and clinical use of methotrexate. N. Engl. J. Med., 309: 1094.
[2] Muriel J Montbriand (2006): Herbs or Natural Products That Protect Against Cancer Growth Part Three of a Four-Part Series. Oncol Nurs Forum. ,33(4):684.

[3] Terry P, Lichtenstein P, Feychting M, Ahlbom $A$ and Wolk A (2001): Fatty fish consumption and risk of prostate cancer. Lancet, 357: 1764-1766.

[4] Ogilvie GK, Fettman MJ, Mallinckrodt CH, Walton JA, Hansen RA and Davenport DJ (2000): Effect of fish oil, arginine, and doxorubicin chemotherapy on remission and survival time for dogs with lymphoma: A double-blind, randomized placebo-controlled study. Cancer, 88: 1916-1928.

[5] Leenhardt F, Fardet A, Lyan B, Gueux E, Rock E, Mazur A, Chanliaud E, Demigne' $C$ and Remesy C (2008): Wheat germ supplementation of a low vitamin $\mathrm{E}$ diet in rats affords effective antioxidant protection in tissues. J. Am. Coll. Nutr., 27: 222-228.

[6] Hassanein MMM and Abedel-Razek AG (2009): Chromatographic quantitation of some bioactive minor components in oils of wheat germ and grape seeds produced as byproducts. J. Oleo Sci., 58: 227-233.

[7] Gelmeza N, Kıncal NS and Yener M E (2009):Optimization of supercritical carbon dioxide extraction of antioxidants from roasted wheat germ based on yield, total phenolic and tocopherol contents, and antioxidant activities of the extracts. J. of Supercritical Fluids, 48: 217-224.

[8] Boyer J and Liu RH (2004): Apple phytochemicals and their health benefits. Nutr J.,3: 5.

[9] Liu JR, Dong H W, Chen BQ, Zhao P and Rui H L (2009): Fresh apples suppress mammary carcinogenesis and proliferative activity and induce apoptosis in mammary tumors of the sprague-dawley rat. Journal of Agricultural and Food Chemistry, 57: 297-304.

[10] Blumenthal M A, Goldberg J Brinkman (2000): Herbal Medicine: Expanded Commision E Monographs. Integrative Medicine Communications. Newton, MA.

[11] Leng-Peschlow E (1991): Plantago ovata seeds as dietary fibre supplement: physiological and metabolic effects in rats. Br. J. Nutr., 66:331349.

[12] Washington NM, Harris A, Musselwhite and Spiller RC (1998): Moderation of lactuloseinduced diarrhea by psyllium: effects on motility and fermentation. Am. J. Clin. Nutr., 67:317-321. 
[13] McCall MR, Mehta T, Leathers CW and Foster DM (1992): Psyllium husk I: effect on plasma lipoproteins, cholesterol metabolism, and atherosclerosis in African green monkeys. Am. J. Clin. Nutr., 56:376-384.

[14] Sierra MJJ, Garcia N Fernández, MJ Diez, AP Calle and Farmafibra Group (2002): Therapeutic effects of psyllium in type 2 diabetic patients. Eur. J. Clin. Nutr., 56:830842.

[15] Cicero AF, Derosa G, Manca M, Bove M, Borghi C and Gaddi AV(2007): Different effect of psyllium and guar dietary supplementation on blood pressure control in hypertensive overweight patients: a six-month, randomized clinical trial. Clin Exp Hypertens., 29(6):383-94.

[16] Paget and Barnes (1964): Evaluation of drug activities paramacometrrics, eds, Laurence and Bacharach, Vol.1, Academic Press., New York. Radical Biology \& Medicine, 40:570 580.

[17] Yosida TM and Amano K (1965): Autosomal Polymorphism in laboratory bred and wild Norway rats,Rattus norvegicus found in Misima. Chromosoma., 16: 658-667.

[18] Mukherjee A, Giri AK, Sharma A and Talukder G (1988): Relative efficacy of short-term tests in detecting genotoxic effects of cadmium chloride in mice in vivo. Mutation Res, 206(2):285-95.

[19] Snedecor GW (1946): Statistical methods, 4th edition. Iowa State, College Press, Amer. Iowa.

[20] Aljanabi SM and Martinez I (1997): Universal and rapid salt extraction of high quality genomic DNA for PCR based techniques. Nucleic Acids Research, 25:4692-4693.

[21] Hassab El-Nabi SE (2004): Molecular and cytogenetic studies on the antimutagenic potential of eugenol in human lymphocytes culture treated with depakine and apetryl drugs. J. Egypt. Ger. Soc. Zoology, (43c): 171-196.

[22] Hassab El-Nabi SE, Mohamed AH and Osman GY (2002): Estimation of RNA electrophoretic pattern as an indicator of pollution in Biomphalaria alexandrina snails treated with certain plant growth regulators, a herbicide and lead acetate. J.Union Arab Biol., 15(A):1467-487.

[23] Cronstein BN (2005): Low-Dose Methotrexate: A Mainstay in the Treatment of Rheumatoid Arthritis". Pharmacological Reviews, 57 (2): 163-172.
[24] Jolly LE, Fletcher HP (1997): The effect of repeated oral dosing of methotrexate on its intestinal absorption in the rat. Toxicol Appl Pharmacol.,39:23-32.

[25] Margolis S, Philips FS and Sternberg SS (1971): The cytotoxicity of methotrexate in mouse small intestine in relation to inhibition of folic acid reductase and DNA synthesis. Cancer Res., 31:2037-46.

[26] Taminiau JA, Gall DG and Hamilton JR (1980): Response of the rat small-intestine epithelium to methotrexate. Gut.,21:486-92.

[27] American Cancer Society (2011): Chemotherapy Principles: An Indepth Discussion of the Techniques and Its Role in Cancer Treatment. www.cancer.org.

[28] Djuric Z, Chen G, Doerge DR, Heilbrun LK and Kucuk $O$ (2001): Effect of soy isoflavone supplementation on markers of oxidative stress in men and women. Cancer Lett., 172:1-6.

[29] Pohar K, Gong M, Bahnson R, Miller E and Clinton S (2003): Tomatoes, lycopene and prostate cancer: a clinician's guide for counseling those at risk for prostate cancer. World J. Urol., 21:9-14.

[30] Djoussé L, Akinkuolie AO, Wu JH, Ding EL And Gaziano JM (2012): Fish consumption, omega-3 fatty acids and risk of heart failure: A meta-analysis., Clin Nutr., (6):846-53.

[31] Hu FB and Manson JE (2012): Omega-3 fatty acids and secondary prevention of cardiovascular disease-is it just a fish tale?: comment on "Efficacy of omega-3 fatty acid supplements (eicosapentaenoic acid and docosahexaenoic acid) in the secondary prevention of cardiovascular disease. Arch Intern Med., 172(9):694-6.

[32] Jensen MK, Koh-Banerjee P, Hu FB, Franz $M$ and Sampson L (2004): Intake of whole grains, bran and germ and the risk of coronary heart disease in men. Am. J. Clin. Nutr., 80: 1492-1499.

[33] Lui RH (2007): Whole grain phytochemicals and health. J. Cereal Sci., 46: 207-219.

[34] Shia CS, Tsai SY, Kuo SC, Hou YC, Chao PD (2009): Metabolism and pharmacokinetics of 3,30,40,7tetrahydroxyflavone (fisetin), 5 hydroxyflavone, and 7-hydroxyfla-vone and antihemolysis effects of fisetin and its serum metabolites. J Agric Food Chem., 57:83-9.

[35] Cui Y, Morgenstern H, Greenland S, Tashkin DP, Mao JT, Cai L, Cozen W, Mack TM, Lu QY and Zhang ZF (2008): Dietary 
flavonoid intake and lung cancer - a population-based case-control study. Cancer, 112: 2241-2248.

[36] Segal I, Hassan H, Walker ARP, Becker P and Braganza J (1995): Faecal short chain fatty acids in South African urban Africans and whites. Dis Colon Rectum., 38 :732-4.

[37] Alberts DS, MartÃnez ME and Roe DJ (2000): Lack of effect of a high-fiber cereal supplement on the recurrence of colorectal adenomas. N Eng J Med., 342(16):1156-1162.

[38] Mondello C, Giorgi $R$ and Nuzzo F (1984): Chromosomal effects of methotrexate on cultured human lymphocytes. Mutat Res., 139(2):67-70.

[39] Choudhury RC, Ghosh SK and Palo AK (2000):Cytogenetic toxicity of methotrexate in mouse bone marrow. Environmental Toxicology and Pharmacology, 8: 191-196.

[40] Stoian V and Raicu P (1975): Morphological Characteristics and the nature of gaps (achromatic lesions) induced by 4Aminouracil in chromosomes of Vicia Faba. Mutation Res, 28: 217-220.

[41] Evan, HJ (1977): Molecular mechanisms in the induction of chromosome aberration.Scott, D. Bridges, B.A.North Holland, Amsterdam, P: 57-74.

[42] Avers C.J. (1980): Genetics, Ch:11, D. Van Nostrand Company, New York, P:417-418.

[43] Brogger, A. (1974): Chromosomes damage in human mitotic cells after in vivo and in vitro exposure to mutagens. Mutation Res., 23:353.

[44] Wissmuller VHF (1971): Untersuchuangen uber diecytogenetische wirkung von phenylbutazone an menshlichen lymphocyten in vitro.Arzneim-Forsch (Drug Res.) Jahragang, 21(11):1938-1950.

[45] Martin SA, McCarthy A, Barber LJ, Burgess DJ, Parry S, Lord CJ and Ashworth A(2009): Methotrexate induces oxidative DNA damage and is selectively lethal to tumour cells with defects in the DNA mismatch repair gene $\mathrm{MSH} 2$. EMBO Molecular Medicine, 1: 323-37.

[46] Frouin I, Prosperi E, Denegri M, Negri C, Donzelli M, Rossi L, Riva F, Stefanini $M$ and Scovass AI (2001): Different effects of methotrexate on DNA mismatch repair proficient and deficient cell: Eur. J. Cancer 37: 1173-1180.

[47] Dadhania VP, Tripathi DN, Vikram A, Ramarao $P$ and Jena GB (2010): Intervention of $\alpha$-lipoic acid ameliorates methotrexate-induced oxidative stress and genotoxicity: A study in rat intestine. Chemico-Biological Interactions, 183: 85-97.

[48] Singh NP (2000): Asimple method for accurate estimation of apoptotic cells. Exper. Cell Res., 256: 328-337.

[49] Hong MY, Bancroft LK, Turner ND, Davidson LA, Murphy ME, Carroll RJ, Chapkin RS and Lupton JR (2005): Fish oil decreases oxidative DNA damage by enhancing apoptosis in rat colon. Nutr Cancer., 52(2):166-75.

[50] Manna S, Janarthan M, Ghosh B, Rana $B$, Rana $A$ and Chatterjee $M$ (2010): Fish oil regulates cell proliferation, protect DNA damages and decrease HER-2/neu and c-Myc protein expression in rat mammary carcinogenesis. Clin Nutr., 29(4):531-7.

[51] Liu R H, Liu JR and Chen BQ (2005): Apples prevent mammary tumors in rats. Journal of Agricultural and Food Chemistry., 53: 23412343.

[52] Adhami VM, Syed DN, Khan N and Mukhtar H (2012): Dietary flavonoid fisetin: A novel dual inhibitor of PI3K/Akt and mTOR for prostate cancer management . Biochem. Pharm., (10):1277-81.

[53] Slavin J (2003): Why whole grains are protective: biological mechanisms. The Nutrition Society, 62:129 -134.

[54] Choudhury RC, Ghosh SK, and Palo AK (2001): Potential transmission of the cytogenetic toxic effects of methotrexate in the male germline cells of Swiss mice. Environmental Toxicology and Pharmacology, 10: 81-88.

[55] Padmanabhan S, Tripathi DN, Vikram A, Ramarao $P$ and Jena GB(2009): Methotrexate-induced cytotoxicity and genotoxicity in germ cells of mice: Intervention of folic and folinic acid Mutation Research/Genetic Toxicology and Environmental Mutagenesis, 673: 43-52.

[56] Morris LF, Harrod MJ, Menter MA And Silverman AK (1993): Methotrexate and reproduction in men: case report and recommendations.Journal of the American Academy of Dermatology, 29(5): 913-916.

[57] Kaczmarski F (1972): Ultrastructural abnormalities of spermatozoon heads in two inbred strains of mice, Bulletin del, Academie polonaise des sciences biologiques CI,II.20, P:103-106.

[58] Topham JC (1980): Do induced sperm head abnormalities in mice specifically identify mammalian mutagens rather than carcinogens, Mutation Res., 74: 397-387. 
Table (1): Average of structural abnormalities observed in bone marrow cells of mice treated with MTX and protected with Omega, Ap or Ps.

\begin{tabular}{|c|c|c|c|c|c|c|c|c|c|c|c|c|c|c|c|c|c|c|c|c|c|c|}
\hline \multirow{3}{*}{1} & \multirow{3}{*}{\begin{tabular}{|l|} 
\\
Groups \\
Control \\
\end{tabular}} & \multicolumn{21}{|c|}{ Mean \pm SD } \\
\hline & & \multicolumn{3}{|c|}{ Deletion } & \multicolumn{3}{|c|}{ Fragmentation } & \multicolumn{2}{|c|}{$\begin{array}{c}\text { Centromeric } \\
\text { attenuation }\end{array}$} & $\begin{array}{l}\text { Centric } \\
\text { Fusion } \\
\end{array}$ & \multicolumn{3}{|c|}{\begin{tabular}{|c||} 
Chromosomal \\
Ring \\
\end{tabular}} & \multicolumn{2}{|c|}{$\begin{array}{l}\text { End to end } \\
\text { association } \\
\end{array}$} & \multicolumn{2}{|r|}{ Breaks } & \multicolumn{2}{|r|}{ Gaps } & \multicolumn{3}{|c|}{ Total } \\
\hline & & 2.2 & \pm & 1.48 & 2 & \pm & 1.22 & 0.8 & \pm 0.84 & $0 \pm 0.55$ & 1 & \pm & 0.55 & 0.4 & \pm 0.55 & & \pm 0.55 & $\mathbf{0}$ & \pm 0.55 & 7.40 & \pm & 6.28 \\
\hline 2 & MTX & 23 & \pm & $3.36 * * *$ & 49 & \pm & $2.48 * * *$ & 8.8 & $\pm 2.39 * *$ & $9 \pm 2.35 * *$ & 6 & \pm & $1.52 * *$ & 18.6 & $\pm 1.95 * * *$ & & $\pm 1.3 * * *$ & 19 & $\pm 2.41 * * *$ & 141.40 & \pm & 17.76 \\
\hline 3 & Omega & 1 & \pm & 1.00 & 3 & \pm & 0.89 & 0.8 & $\pm \quad 0.84$ & $0 \pm 0.55$ & $\mathbf{0}$ & \pm & 0.55 & 0.6 & $\pm \quad 0.55$ & & \pm 0.55 & $\mathbf{0}$ & $\pm \quad 0.55$ & 7.60 & \pm & 5.47 \\
\hline 4 & Apple & 1.6 & \pm & 0.55 & 3 & \pm & 1.92 & 1.8 & \pm 0.45 & $1 \pm 0.00$ & 1 & \pm & 0.84 & 1.8 & $\pm \quad 0.84$ & & \pm 0.84 & 1 & 0.55 & 11.60 & \pm & 5.98 \\
\hline 5 & Psyllium & 2.4 & \pm & 0.55 & 4 & \pm & 2.59 & 2.6 & \pm 0.55 & $1 \pm 0.00$ & 1 & \pm & 0.84 & 2.8 & $\pm \quad 0.84$ & & \pm 0.71 & 1 & $\pm \quad 1.10$ & 16.00 & \pm & 7.16 \\
\hline 6 & MTX +Omega & 8.4 & \pm & $1.14 * *$ & 10 & \pm & $1.58 * * *$ & 6 & $\pm 0.71 * * *$ & $4 \pm 0.84 * *$ & 3 & \pm & $1.1 * *$ & 2.2 & $\pm \quad 1.79$ & & $\pm \mathbf{1 . 5 2}$ & 4 & $\pm 1.30 * *$ & 40.20 & \pm & 9.97 \\
\hline 7 & MTX+Apple & 9 & \pm & $1.22 * *$ & 8 & \pm & $1.14 * *$ & 6.2 & $\pm 0.84 * * *$ & $4 \pm 1 * *$ & 4 & \pm & $2.3^{*}$ & 3.8 & $\pm 0.84 * *$ & & $\pm 0.89 * *$ & 3 & $\pm 1.30 *$ & 41.20 & \pm & 9.54 \\
\hline 8 & MTX+Psyllium & 8.6 & \pm & $2.19 * *$ & 11 & \pm & $1.14 * * *$ & 4.2 & $\pm 0.84 * *$ & $4 \pm 1.3 * *$ & 4 & \pm & $0.84 * *$ & 3.8 & $\pm 0.84 * *$ & & $\pm 1.3 * *$ & 4 & $\pm 0.55 * * *$ & 44.40 & \pm & 9.00 \\
\hline 9 & MTX after Omega & 18 & \pm & $2.7 * * *$ & 38 & \pm & $2.92 * * *$ & 5 & $\pm 1.58 * *$ & $5 \pm 1.14 * *$ & 5 & \pm & $1.14 * *$ & 9 & $\pm 1.58 * * *$ & & $\pm 0.84 * *$ & 8 & $\pm 1.92 * * *$ & 93.40 & \pm & 13.82 \\
\hline 10 & MTX after Apple & 7.6 & \pm & $1.14 * *$ & 8 & \pm & $1.30 * *$ & 2.6 & $\pm \quad 1.82$ & $2 \pm 1.92$ & 2 & \pm & 1.30 & 1.6 & $\pm \quad 1.14$ & & $\pm 1.67 * * *$ & 2 & $\pm \quad 1.67$ & 27.40 & \pm & 11.97 \\
\hline 11 & MTX after Psyllium & 9.8 & \pm & $1.48 * *$ & 10 & \pm & $2.07 * *$ & 5.2 & $\pm 1.79 * *$ & $4 \pm 1.14 * *$ & 2 & \pm & 1.22 & 1.8 & $\pm \quad 1.48$ & & \pm 1.22 & 2 & $\pm 1.41 *$ & 36.80 & \pm & 11.83 \\
\hline 12 & MTX before Omega & 7.4 & \pm & $1.14 * *$ & 7 & \pm & $1.58 * *$ & 1.8 & \pm 1.79 & $3 \pm 1.14 *$ & 2 & \pm & $2.07 *$ & 3.4 & $\pm 1.82 *$ & & \pm 1.48 & 1 & $\pm \quad 1.00$ & 27.80 & \pm & 12.02 \\
\hline 13 & MTX before Apple & 19 & \pm & $2.3 * * *$ & 40 & \pm & $3.11 * * *$ & 4.2 & $\pm 1.92 *$ & $4 \pm 1.58 * * *$ & 4 & \pm & 1.58 & 11.8 & $\pm 2.39 * * *$ & & \pm 1.58 & 4 & 3.16 & 91.60 & \pm & 17.63 \\
\hline 14 & MTX before Psyllium & 18 & \pm & $3.49^{* * * *}$ & 40 & \pm & $2.59 * * *$ & 3.8 & $\pm 1.48 *$ & $3 \pm 1.14 * *$ & 4 & \pm & $0.84 *$ & 11.8 & $\pm 2.59 * * *$ & & \pm 2.49 & 4 & $\pm \quad 1.14$ & 89.40 & \pm & 15.76 \\
\hline
\end{tabular}

* Significant $(\mathbf{p}<=0.05), \quad * *$ Highly Significant $(\mathbf{p}<=0.01), \quad * * *$ Very Highly Significant $(\mathbf{p}<=0.001)$

MTX = Methotrexate,$\quad$ Omega $=$ Omega-3-Plus,$\quad$ Ps $=$ Psyllium,$\quad$ Ap $=$ Apple 
Table (2): Average of numerical chromosomal abnormalities and mitotic index observed in bone marrow cells of mice treated with MTX and protected with Omega, Ap or Ps.

\begin{tabular}{|c|c|c|c|c|c|c|c|c|c|c|c|c|c|c|c|c|}
\hline \multirow{2}{*}{\multicolumn{2}{|c|}{ Groups }} & \multicolumn{12}{|c|}{ Mean \pm SD } & \multirow{2}{*}{\multicolumn{3}{|c|}{ Mitotic Index }} \\
\hline & & \multicolumn{3}{|c|}{ Monosomy } & \multicolumn{3}{|c|}{ Trisomy } & \multicolumn{3}{|c|}{ Polyolidy } & \multicolumn{3}{|c|}{ Total } & & & \\
\hline 1 & Control & $\mathbf{0}$ & \pm & 0.00 & 0.2 & \pm & 0.45 & $\mathbf{0}$ & \pm & 0.00 & 0.20 & \pm & 0.45 & 570 & \pm & 23.72 \\
\hline 2 & MTX & 5.6 & \pm & $0.89 * * *$ & 6.2 & \pm & $1.92 * *$ & 9.8 & \pm & $1.48 * * *$ & 21.60 & \pm & 4.30 & 221 & \pm & 5.87 \\
\hline 3 & Omega & $\mathbf{0}$ & \pm & 0.00 & $\mathbf{0}$ & \pm & 0.00 & 0 & \pm & 0.00 & 0.00 & \pm & 0.00 & 567.4 & \pm & 24.06 \\
\hline 4 & Apple & $\mathbf{0}$ & \pm & 0.00 & $\mathbf{0}$ & \pm & 0.00 & $\mathbf{0}$ & \pm & 0.00 & 0.00 & \pm & 0.00 & 588.8 & \pm & 25.84 \\
\hline 5 & Psyllium & 0 & \pm & 0.00 & 0 & \pm & 0.00 & 0 & \pm & 0.00 & 0.00 & \pm & 0.00 & 599 & \pm & 31.88 \\
\hline 6 & MTX +Omega & 2.8 & \pm & $0.84^{* *}$ & 1.8 & \pm & $1.1^{*}$ & 4.6 & \pm & $1.67 * *$ & 9.20 & \pm & 3.61 & 579.2 & \pm & 6.80 \\
\hline 7 & MTX+Apple & 4.2 & \pm & $1.30^{* *}$ & 1.2 & \pm & 1.30 & 5 & \pm & $1.58 * *$ & 10.40 & \pm & 4.19 & 562.4 & \pm & 3.97 \\
\hline 8 & MTX+Psyllium & 2.6 & \pm & $1.5 *$ & 2 & \pm & 1.22 & 7.2 & \pm & $0.84 * * *$ & 11.80 & \pm & 3.58 & 553.4 & \pm & 4.39 \\
\hline 9 & MTX after Omega & 3.8 & \pm & $0.84 * * *$ & 4.6 & \pm & 1.14 & 8 & \pm & $1.58 * * *$ & 16.40 & \pm & 3.56 & 250.2 & \pm & 2.39 \\
\hline 10 & MTX after Apple & 1.4 & \pm & $0.89^{*}$ & 1 & \pm & 1.00 & 4.4 & \pm & $1.14 * * *$ & 6.80 & \pm & 3.03 & 406 & \pm & 8.63 \\
\hline 11 & MTX after Psyllium & 1.4 & \pm & $1.14 *$ & 1.2 & \pm & 1.30 & 6.2 & \pm & $1.92 * *$ & 8.80 & \pm & 4.37 & 350.2 & \pm & 3.70 \\
\hline 12 & MTX before Omega & 0.8 & \pm & 0.84 & 0.8 & \pm & 0.84 & 4 & \pm & $1 \% * *$ & 5.60 & \pm & 2.67 & 550.2 & \pm & 6.02 \\
\hline 13 & MTX before Apple & 2.6 & \pm & $1.52^{*}$ & 3.2 & \pm & $1.48^{*}$ & 5 & \pm & $1.58 * *$ & 10.80 & \pm & 4.58 & 220.8 & \pm & 3.42 \\
\hline 14 & MTX before Psyllium & 3 & \pm & $2.23^{*}$ & 3 & \pm & $1.58 *$ & 4.8 & \pm & $0.84^{*}$ & 10.80 & \pm & 4.65 & 222.6 & \pm & 3.36 \\
\hline
\end{tabular}

* Significant $(\mathbf{p}<=0.05)$,

MTX = Methotrexate,
** Highly Significant $(\mathbf{p}<=0.01)$,

Omega = Omega-3-Plus,
$* * *$ Very Highly Significant $(\mathbf{p}<=0.001)$

Ps = Psyllium,

Ap $=$ Apple 
Table (3): Average of sperm head abnormalities observed in bone marrow cells of mice treated with MTX and protected with Ap, Omega or Ps.

\begin{tabular}{|c|c|c|c|c|c|c|c|c|c|c|c|c|c|}
\hline \multirow[b]{3}{*}{1} & \multirow{3}{*}{$\begin{array}{l}\text { Groups } \\
\text { Control }\end{array}$} & \multicolumn{12}{|c|}{ Sperm head abnormalities } \\
\hline & & \multicolumn{3}{|c|}{ Without hook } & \multicolumn{3}{|c|}{ Banana } & \multicolumn{3}{|c|}{ Amorphous } & \multicolumn{3}{|l|}{ Total } \\
\hline & & 4.4 & \pm & 0.55 & 3 & \pm & 1.00 & 3.6 & \pm & $2.07 * * *$ & 11 & \pm & 1.55 \\
\hline 2 & MTX & 17 & \pm & $2.65^{* * * *}$ & 26.6 & \pm & $3.21 * * *$ & 86 & \pm & 7.91 & 129.6 & \pm & 7.91 \\
\hline 3 & Omega & 3 & \pm & 1.00 & 2.8 & \pm & 1.48 & 2.8 & \pm & 1.30 & 8.6 & \pm & 3.79 \\
\hline 4 & Apple & 3 & \pm & 1.87 & 2.8 & \pm & 1.10 & 4.2 & \pm & 0.45 & 10 & \pm & 3.41 \\
\hline 5 & Psyllium & 4.2 & \pm & 1.64 & 4.2 & \pm & 1.10 & 3.6 & \pm & $0.89 * * *$ & 12 & \pm & 2.74 \\
\hline 6 & MTX +Omega & 3.4 & \pm & 1.14 & 7 & \pm & $1.58 * *$ & 47.8 & \pm & $3.03 * *$ & 58.2 & \pm & 1.14 \\
\hline 7 & MTX+Apple & 2.2 & \pm & $\mathbf{0 . 8 4} * *$ & 7.8 & \pm & $1.92 * *$ & 58 & \pm & $1.58 * *$ & 68 & \pm & 0.00 \\
\hline 8 & MTX+Psyllium & 6.2 & \pm & 1.64 & 7.8 & \pm & $1.92 * *$ & 58.2 & \pm & $2.38 * *$ & 72.2 & \pm & 1.64 \\
\hline 9 & MTX after Omega & 1.6 & \pm & $0.89 * *$ & 3.6 & \pm & 0.89 & 42 & \pm & $2.12 * *$ & 47.2 & \pm & 0.89 \\
\hline 10 & MTX after Apple & 2.6 & \pm & 1.67 & 1.6 & \pm & 1.34 & 46.4 & \pm & $3.05 * * *$ & 50.6 & \pm & 3.01 \\
\hline 11 & $\begin{array}{l}\text { MTX after } \\
\text { Psyllium }\end{array}$ & 5.4 & \pm & 1.14 & 3.8 & \pm & 0.84 & 54 & \pm & $3.08 * * *$ & 63.2 & \pm & 1.98 \\
\hline 12 & $\begin{array}{l}\text { MTX before } \\
\text { Omega }\end{array}$ & 4 & \pm & 1.58 & 7.2 & \pm & $1.92 *$ & 50.4 & \pm & $2.70 * *$ & 61.6 & \pm & 1.58 \\
\hline 13 & MTX before Apple & 13.4 & \pm & $2.41 * *$ & 23.6 & \pm & $2.70 * * *$ & 68.4 & \pm & $2.4 * *$ & 105.4 & \pm & 0.00 \\
\hline 14 & $\begin{array}{l}\text { MTX before } \\
\text { Psyllium }\end{array}$ & 13.8 & \pm & $1.30 * * *$ & 28.6 & \pm & $2.61 * * *$ & 71.2 & \pm & $4.81 * * *$ & 113.6 & \pm & 0.00 \\
\hline
\end{tabular}

* Significant $(\mathbf{p}<=\mathbf{0 . 0 5})$, MTX = Methotrexate,
** Highly Significant $(\mathrm{p}<=0.01)$, Omega $=$ Omega-3-Plus, $\quad$ Ps $=$ Psyllium,
*** Very Highly Significant $(\mathbf{p}<=0.001)$ Ap = Apple

Table (4) Optical density of intact and apoptotic fragments of DNA at 200, 400, 600 and $800 \mathrm{bp}$ in liver of mices treated with Methotrexate and protected with Omega Ap or Ps.

\begin{tabular}{|c|c|c|c|c|c|}
\hline & Lane 1 & Lane 2 & Lane 3 & Lane 4 & Lane 5 \\
\hline & Control & MTX & Omega & Ap & Ps \\
\hline Intact DNA & 152.22 & 23.575 & 218.15 & 189.2 & 175.3 \\
\hline DNA at 800 bp & 20.2 & 90.908 & 25.294 & 50.294 & 64.77 \\
\hline DNA at 600 bp & 8.37 & 142.99 & 13.247 & 37.541 & 40.77 \\
\hline DNA at 400 bp & 6.45 & 141.02 & 5.152 & 20.153 & 32.851 \\
\hline DNA at 200 bp & 4.23 & 65.08 & 0.58824 & 6.988 & 12.184 \\
\hline $\begin{array}{l}\text { Sum of apoptotic } \\
\text { fragments }\end{array}$ & 39.3 & 439.998 & 44.2 & 115 & 150.6 \\
\hline
\end{tabular}


Table (5): Optical density of intact and apoptotic fragments of DNA at 200,400,600,800bp in liver of mices treated and protected together with MTX and with Omega, Ap or Ps.

\begin{tabular}{llllll}
\hline & Lane 1 & Lane 2 & Lane 3 & Lane 4 & Lane 5 \\
\cline { 2 - 5 } & Control & MTX & MTX+Omega & MTX+Ap & MTX+PS \\
Intact DNA & $\mathbf{1 5 2 . 2 2}$ & $\mathbf{2 3 . 5 7 5}$ & $\mathbf{1 3 4 . 8 6}$ & $\mathbf{1 3 2 . 0 2}$ & $\mathbf{1 1 4 . 9 6}$ \\
DNA at 800 bp & $\mathbf{2 0 . 2}$ & $\mathbf{9 0 . 9 0 8}$ & $\mathbf{7 8 . 0 1 1}$ & $\mathbf{1 1 1 . 7 9}$ & $\mathbf{9 0 . 9 6}$ \\
DNA at 600 bp & $\mathbf{8 . 3 7}$ & $\mathbf{1 4 2 . 9 9}$ & $\mathbf{4 7 . 2 4 1}$ & $\mathbf{7 9 . 1 8 8}$ & $\mathbf{1 2 0 . 4 6}$ \\
DNA at 400 bp & $\mathbf{6 . 4 5}$ & $\mathbf{1 4 1 . 0 2}$ & $\mathbf{3 3 . 1 2 6}$ & $\mathbf{5 5 . 1 2 9}$ & $\mathbf{9 8 . 9 9}$ \\
DNA at 200 bp & $\mathbf{4 . 2 3}$ & $\mathbf{6 5 . 0 8}$ & $\mathbf{1 8 . 5 6 3}$ & $\mathbf{4 4 . 8 1 2}$ & $\mathbf{3 0 . 3 8 8}$ \\
Sum of apoptotic & $\mathbf{3 9 . 3}$ & $\mathbf{4 3 9 . 9 9 8}$ & $\mathbf{1 7 6 . 9 4 1}$ & $\mathbf{2 9 0 . 9 1 9}$ & $\mathbf{3 4 0 . 7 9 8}$ \\
fragments & & & & & \\
\hline
\end{tabular}

Table (6): Optical density of intact and apoptotic fragments of DNA at 200,400,600,800bp in liver of mices treated with MTX after Omega, Ap or Ps.

\begin{tabular}{|c|c|c|c|c|c|}
\hline & Lane 1 & Lane 2 & Lane 3 & Lane 4 & Lane 5 \\
\hline & Control & MTX & MTX after omega & MTX after Ap & MTX after Ps \\
\hline Intact DNA & 152.22 & 23.575 & 33.988 & 106.06 & 63.753 \\
\hline DNA at 800 bp & 20.2 & 90.908 & 31.576 & 66.8 & 33 \\
\hline DNA at 600 bp & 8.37 & 142.99 & 41.282 & 90.02 & 48.8 \\
\hline DNA at 400 bp & 6.45 & 141.02 & 79.012 & 120.46 & 77.8 \\
\hline DNA at 200 bp & 4.23 & 65.08 & 167.45 & 25.329 & 155.39 \\
\hline $\begin{array}{l}\text { Sum of apoptotic } \\
\text { fragments }\end{array}$ & 39.3 & 439.998 & 319.32 & 302.609 & 314.99 \\
\hline
\end{tabular}

Table (7): Optical density of intact and apoptotic fragments of DNA at 200,400,600,800bp in liver of mices treated with MTX before Omega, Ap or Ps.

\begin{tabular}{|c|c|c|c|c|c|}
\hline & Lane 1 & Lane 2 & Lane 3 & Lane 4 & Lane 5 \\
\hline & Control & MTX & MTX before omega & MTX before Ap & MTX before Ps \\
\hline Intact DNA & 152.22 & 23.575 & 103.04 & 23.575 & 21.034 \\
\hline DNA at $800 \mathrm{bp}$ & 20.2 & 90.908 & 45.282 & 90.908 & 51.724 \\
\hline DNA at $600 \mathrm{bp}$ & 8.37 & 142.99 & 65.541 & 92.99 & 116.08 \\
\hline DNA at $400 \mathrm{bp}$ & 6.45 & 141.02 & 90.25 & 91.02 & 116.01 \\
\hline DNA at $200 \mathrm{bp}$ & 4.23 & 65.08 & 109.19 & 45.08 & 28.931 \\
\hline $\begin{array}{l}\text { Sum of apoptotic } \\
\text { fragments }\end{array}$ & 39.3 & 439.998 & 310.3 & 320 & 312.745 \\
\hline
\end{tabular}


Zowail, M.E.M et al

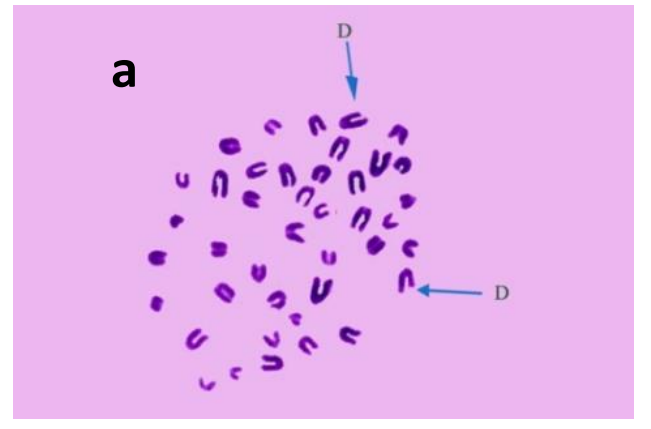

b
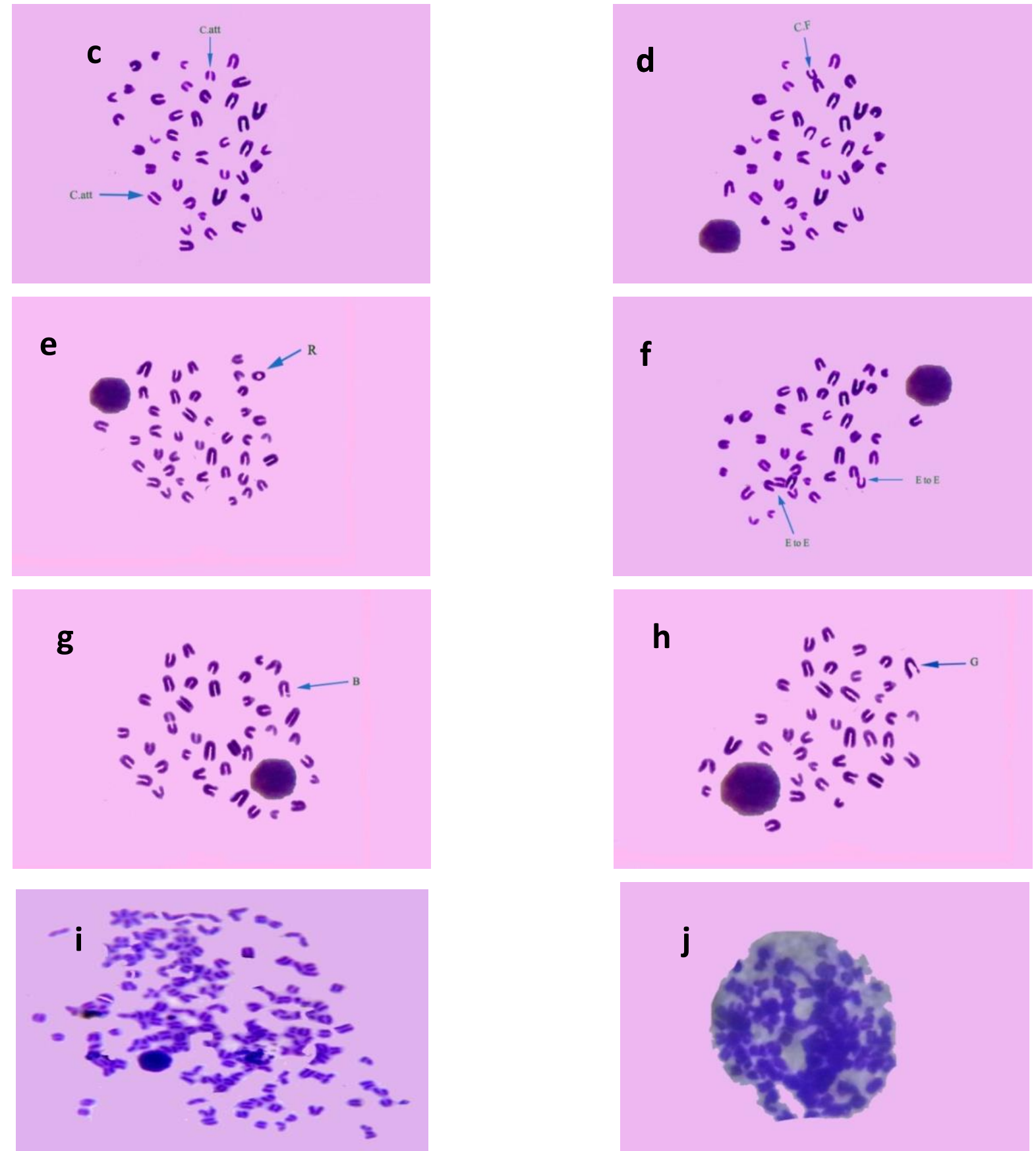

Figure (1): Types of chromosomal aberrations in rat bone marrow cells treated with Methotrexate. a: deletion (D); b:fragmentation (F); c: centromeric attenuation ( $C$ att); d: centric fusion (CF); e: chromosomal ring (R); f: end to end association (E to E); g: break (B); h: gap (G); i: Polyploidy and j: Sticky 


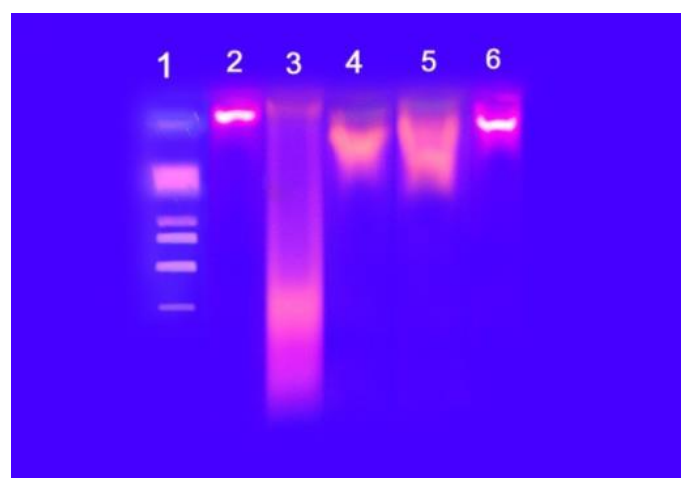

Figure (6): DNA damage in liver of mices treated with MTX and protected with Omega, Ap and Ps.lane1: DNA ladder; lane 2: Control; Lane 3: MTX; lane 4: Omega; lane 5: Ap; lane 6:Ps.

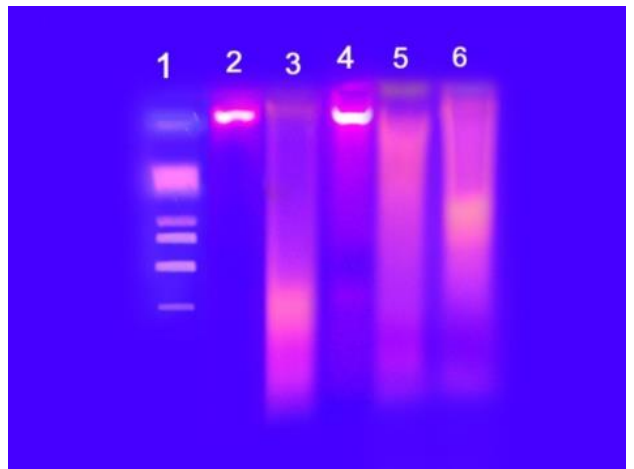

Figure (8): DNA damage in liver of mices treated and protected together with MTX and with Omega, Ap and Ps. lane1: DNA ladder; lane 2: Control; Lane 3: MTX; lane 4: MTX+Omega; lane 5: MTX+Ap; lane 6:MTX+Ps.

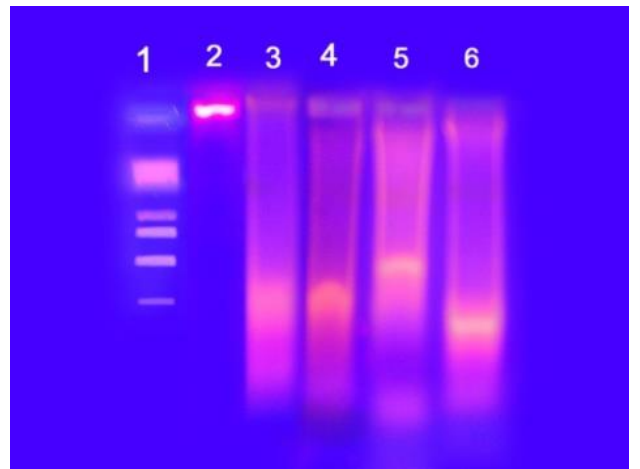

Figure (10): DNA damage in liver of mices treated with MTX after Omega, Ap and Ps. lane1: DNA ladder; lane 2: Control; Lane 3: MTX; lane 4: MTX after Omega; lane 5: MTX after Ap; lane 6:MTX after Ps.

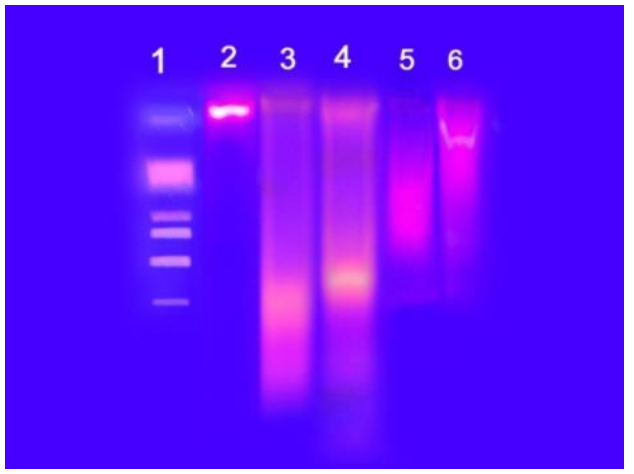

Figure (12): DNA damage in liver of mices treated with MTX before Omega, Ap and Ps. lane1: DNA ladder; lane 2: Control; Lane 3: MTX; lane 4: MTX before Omega; lane 5: MTX before Ap; lane 6:MTX before Ps. 


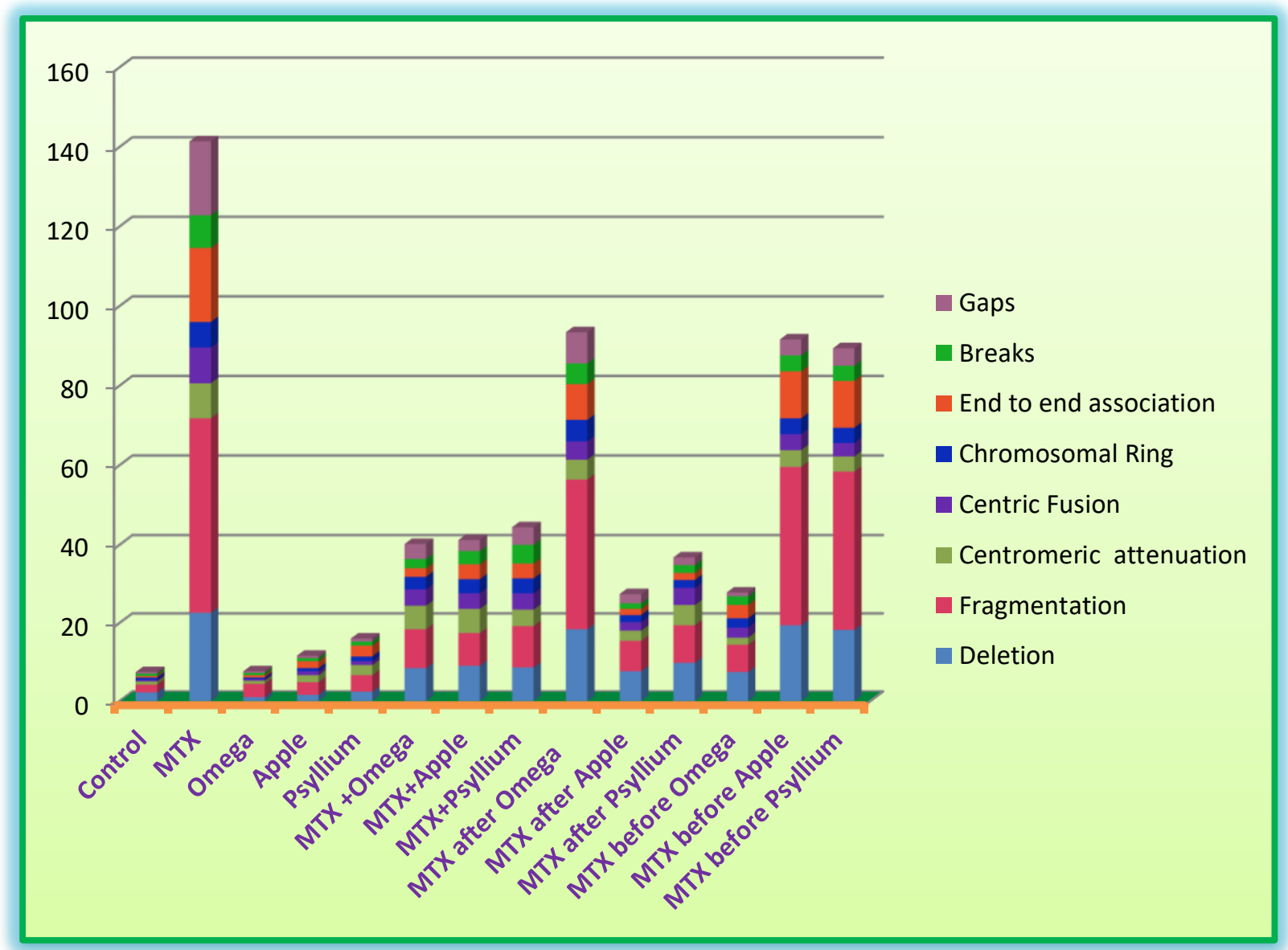

Figure (2): Average of structural abnormalities observed in bone marrow cells of mice treated with MTX and protected with Omega, Ap or Ps.

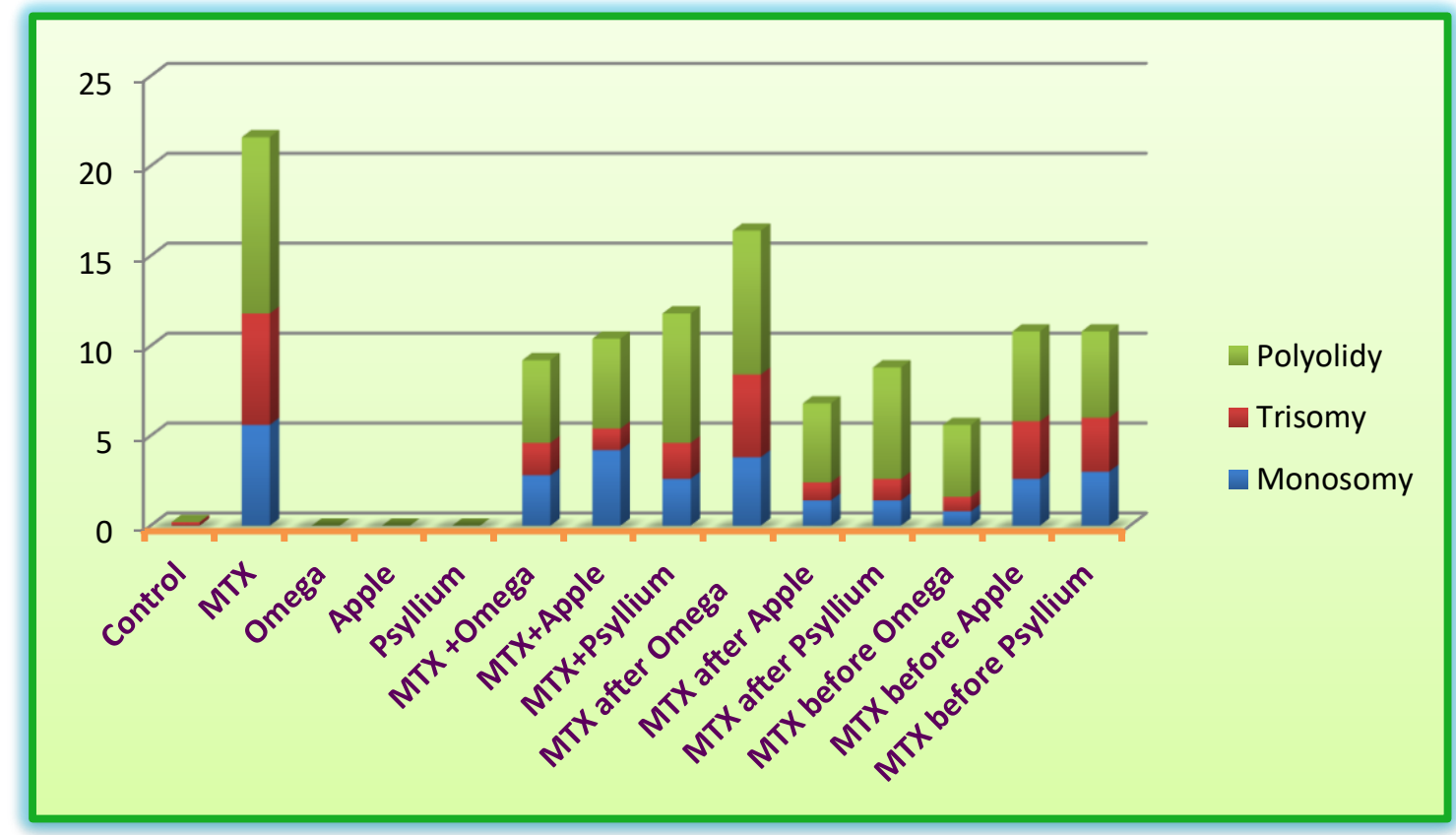

Figure(3): Average of numerical chromosomal abnormalities observed in bone marrow cells of mice treated with MTX and protected with Ap, Omega and Ps. 


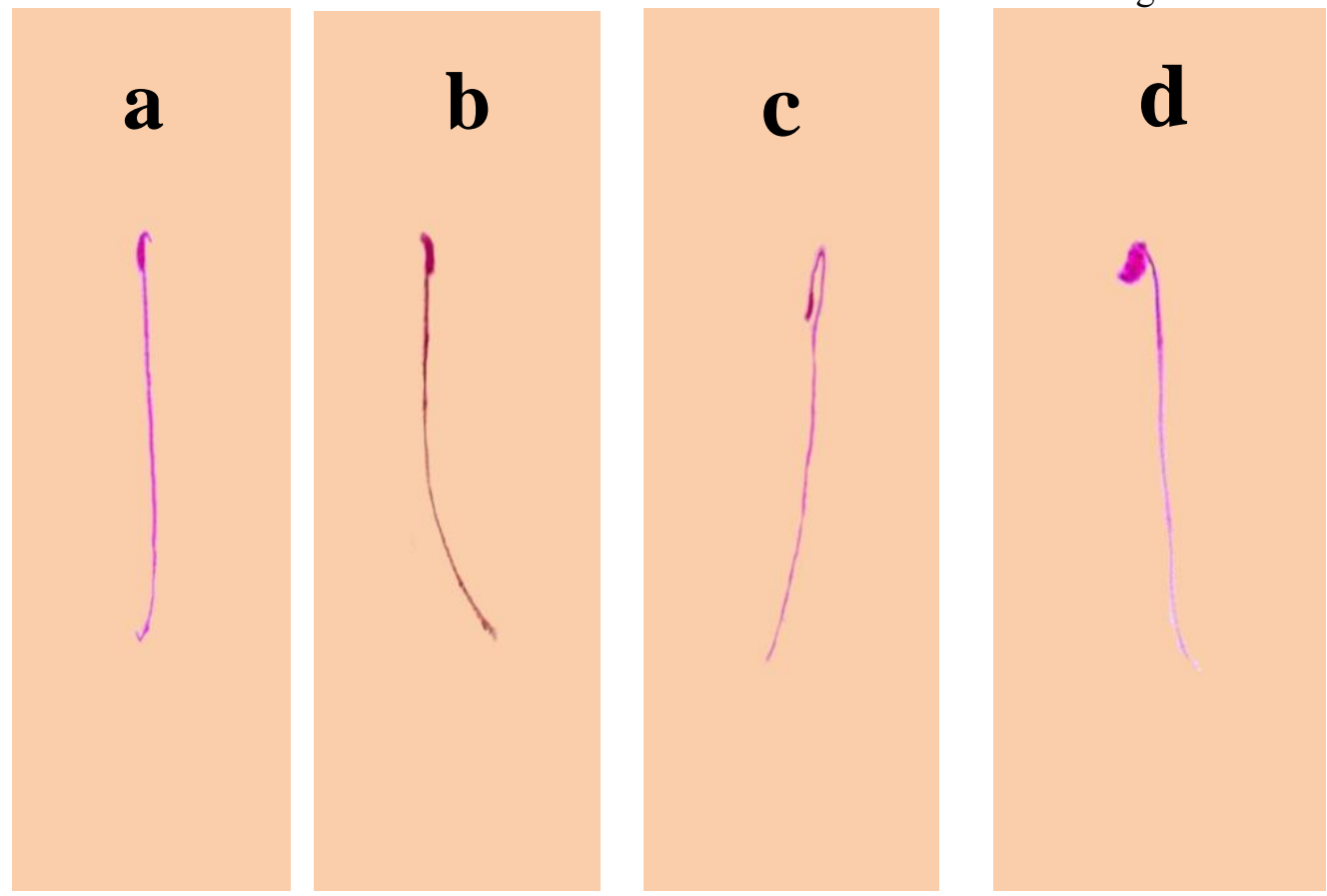

Figure (4): Average of sperm head abnormalities observed in bone marrow cells of mice treated with MTX and protected with Omega Ap or Ps. a: normal sperm; b: without hook; c: banana shape and d: amorphous.

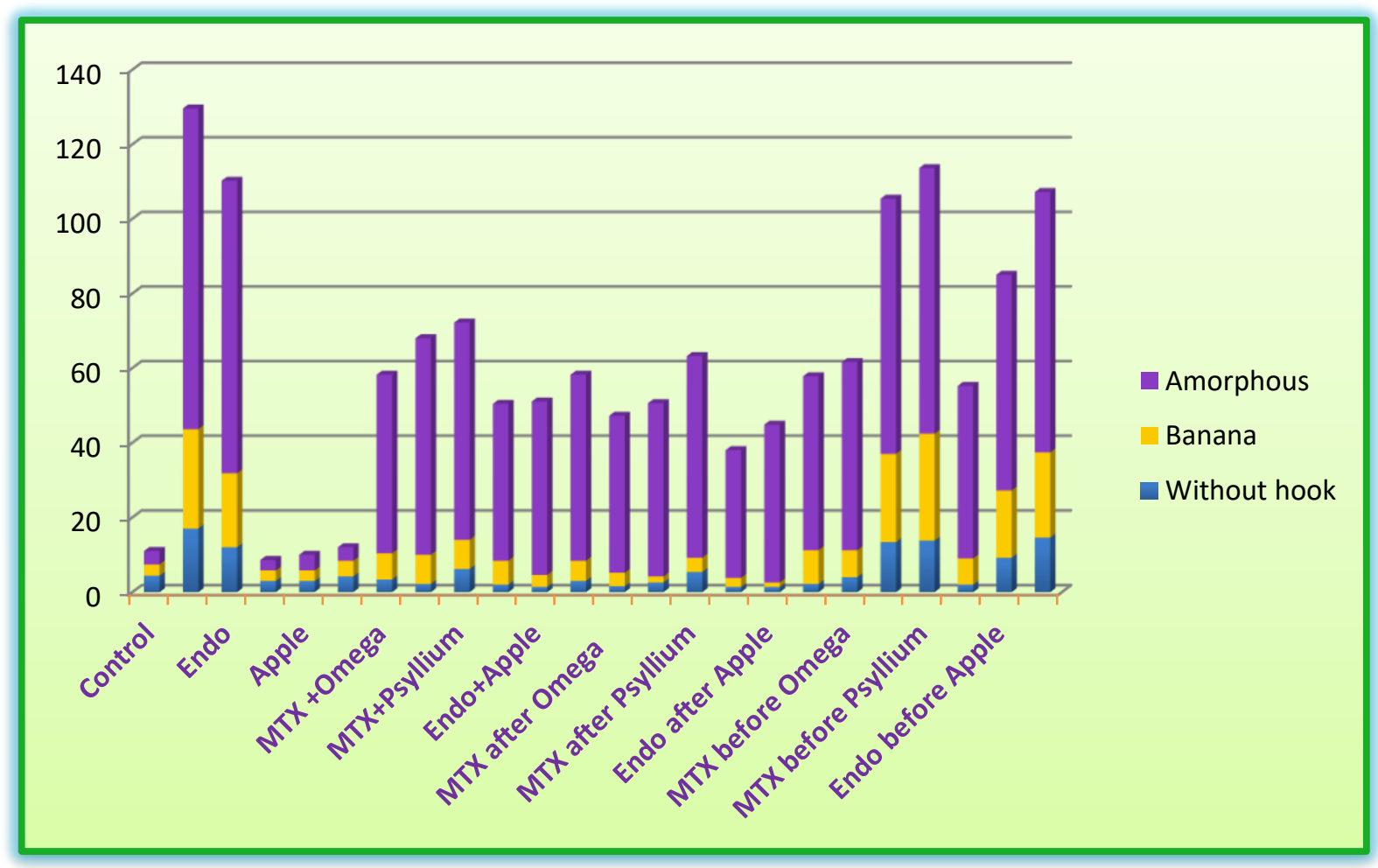

Figure (5): Average of sperm head abnormalities observed in bone marrow cells of mice treated with MTX and protected with Omega, Ap or Ps. 
Optical density of DNA

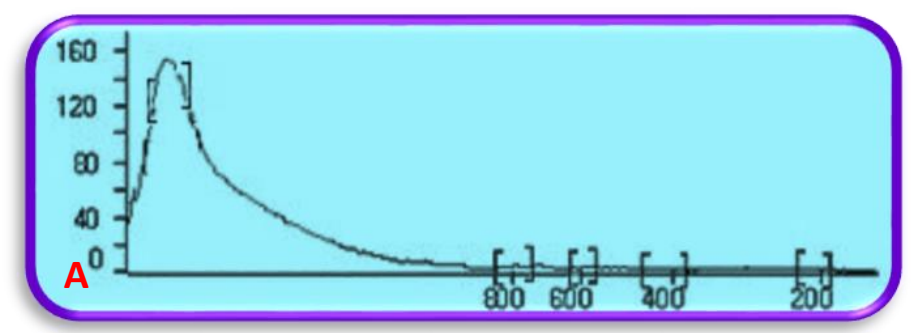

Optical density of DNA

Mol weight in bp

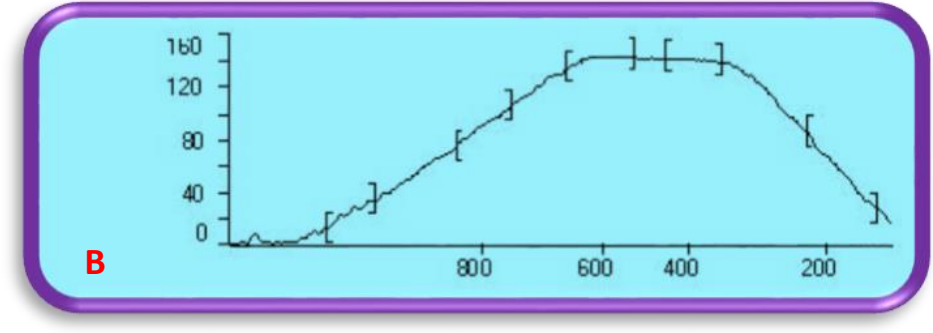

Optical density of DNA

Mol weight in bp

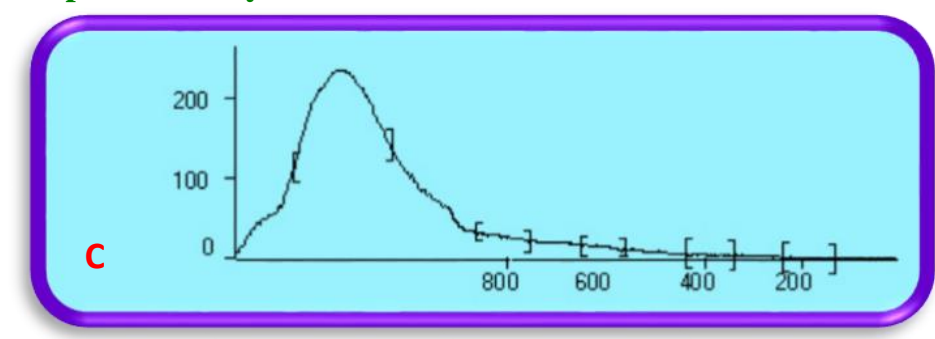

Mol weight in bp

Optical density of DNA

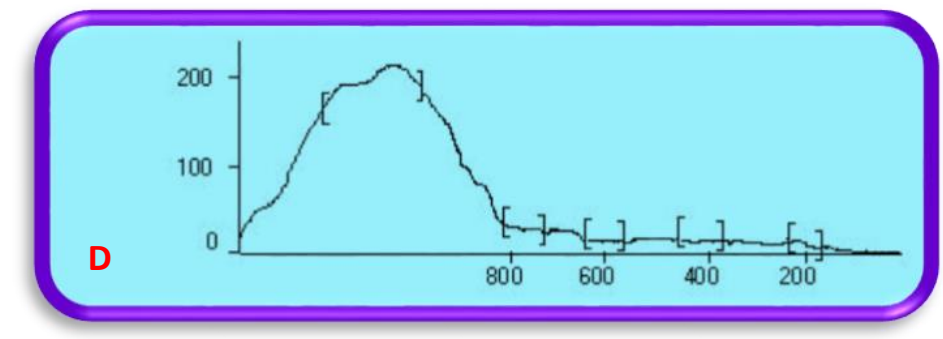

Optical density of DNA

Mol weight in bp

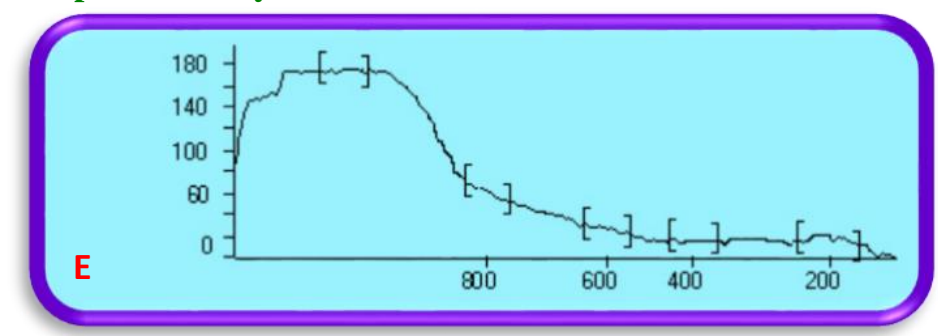

Mol weight in bp

Figure(7): Histograms of optical density of intact and apoptic fragments of DNA at 200, 400, 600 and 800 bp in liver of mices treated with MTX and protected with Omega, Ap and Ps.(A): Control; (B): MTX; (C):Omega-3 Plus; (D): Apple; (E): Psyllium. 
Administration of Three Natural Products as Protective Agents....

Optical density of DNA

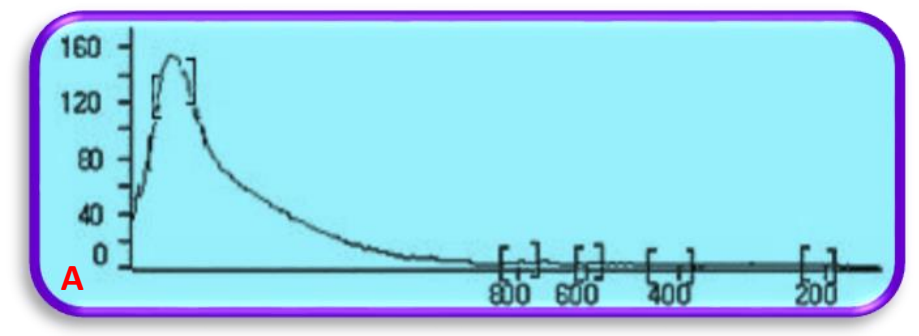

Optical density of DNA

Mol weight in bp

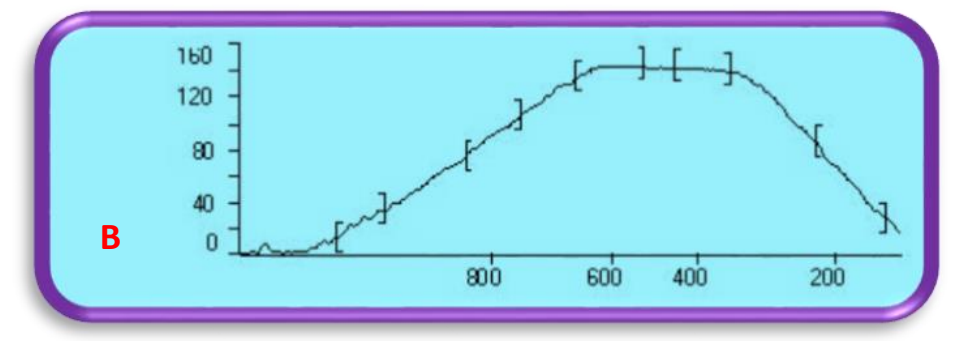

Optical density of DNA

Mol weight in bp

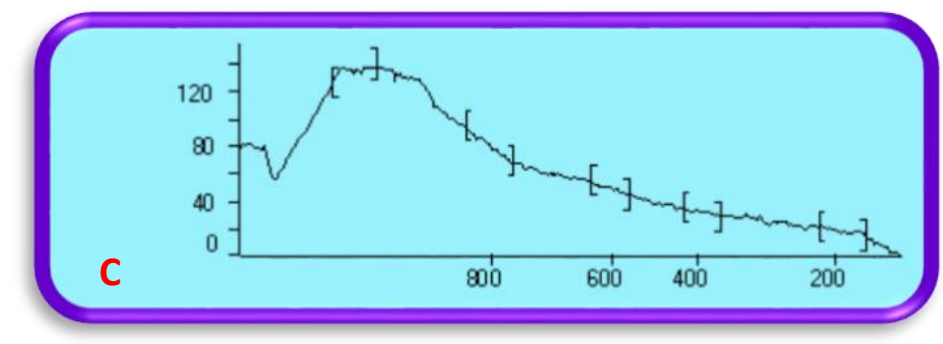

Optical density of DNA

Mol weight in bp

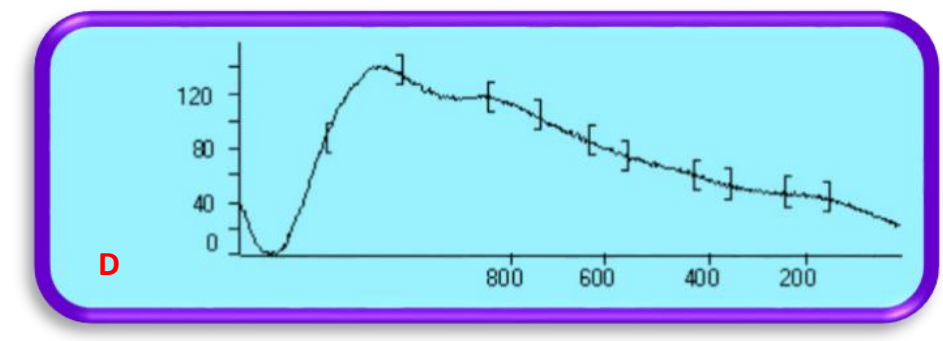

Optical density of DNA

Mol weight in bp

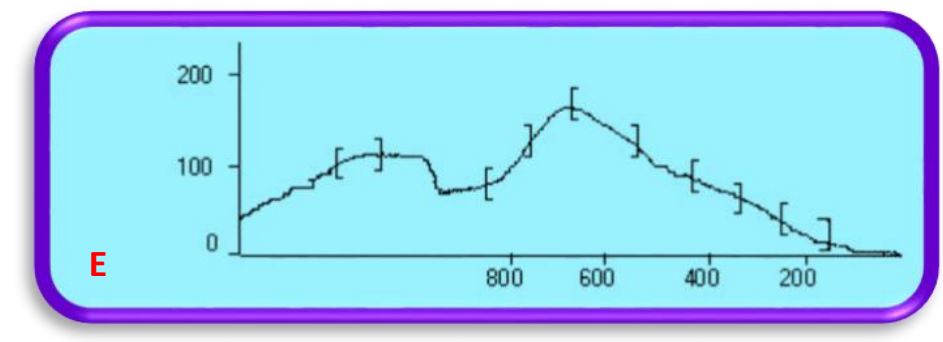

Mol weight in bp

Figure(9): Histograms of optical density of intact and apoptic fragments of DNA at 200, 400, 600 and $800 \mathrm{bp}$ in liver of mices treated and protected together with MTX and with Omega, Ap and Ps. (A): Control; (B): MTX; (C):MTX+Omega; (D):MTX+Apple; (E):MTX+ Psyllium. 
Optical density of DNA

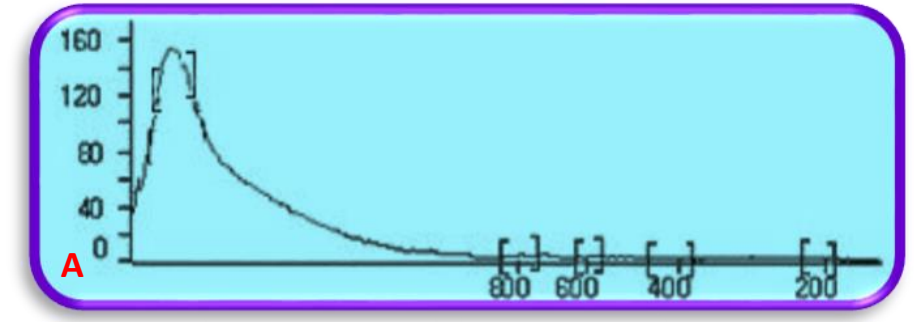

Optical density of DNA

Mol weight in bp

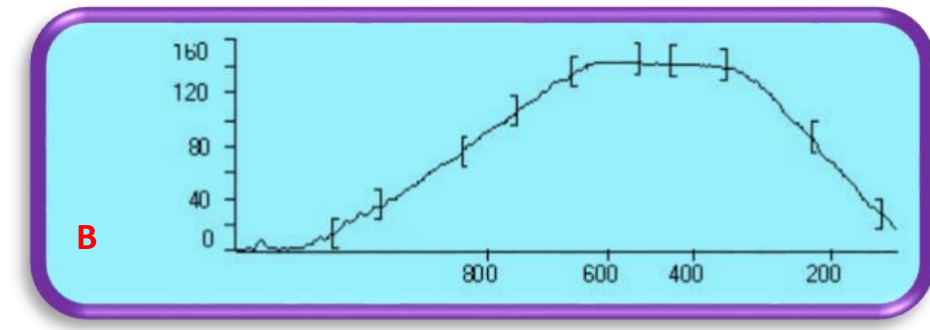

Optical density of DNA

Mol weight in bp

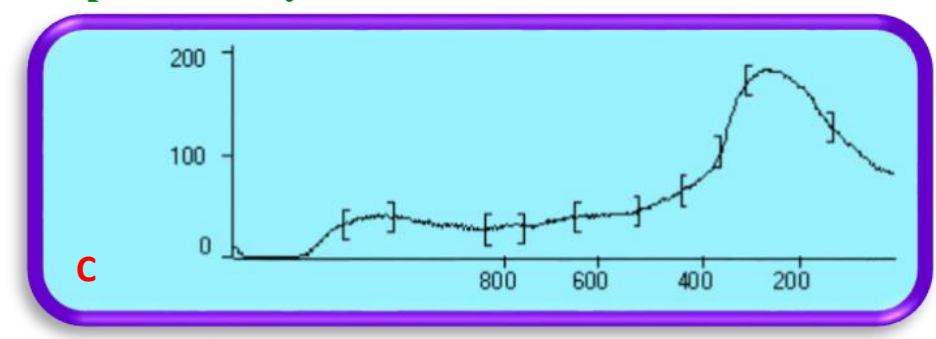

Optical density of DNA

Mol weight in bp

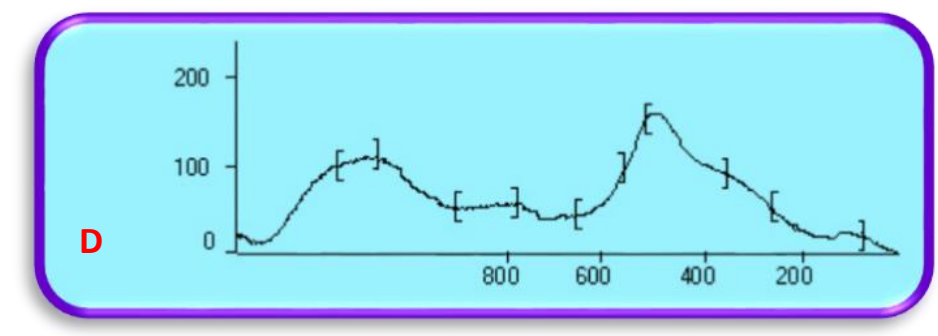

Optical density of DNA

Mol weight in bp

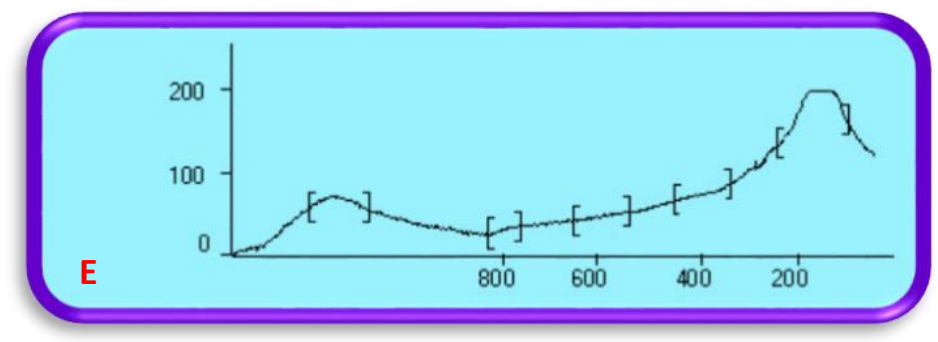

Mol weight in bp

Figure(11): Histograms of optical density of intact and apoptic fragments of DNA at 200, 400, 600 and 800 bp in liver of mices treated with MTX after Omega, Ap and Ps. (A): Control; (B): MTX; (C):MTX afterOmega; (D):MTXafter Apple; (E):MTX after Psyllium. 
Administration of Three Natural Products as Protective Agents....

Optical density of DNA

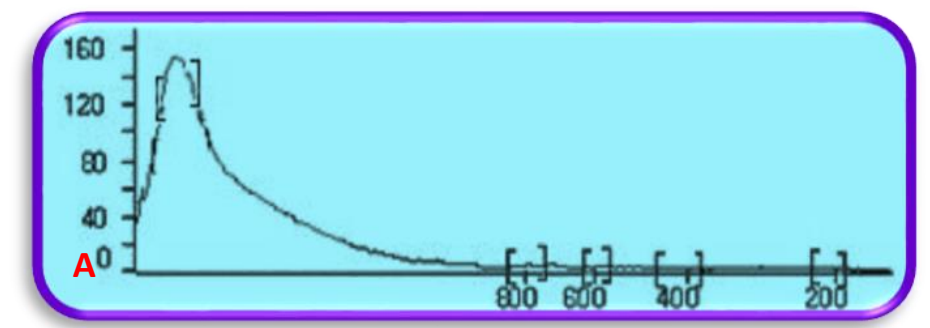

Optical density of DNA

Mol weight in bp

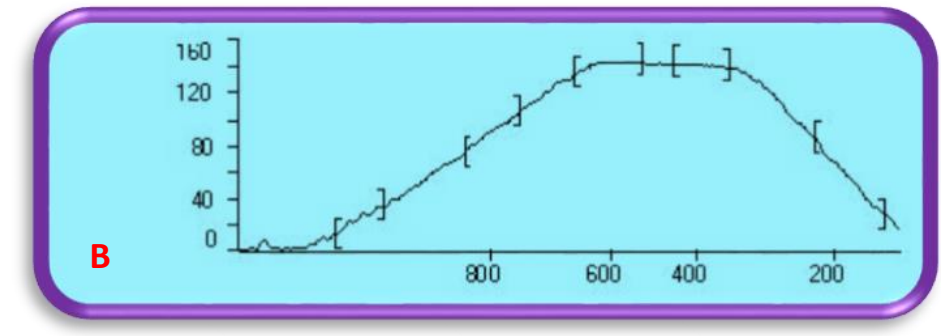

Optical density of DNA

Mol weight in bp

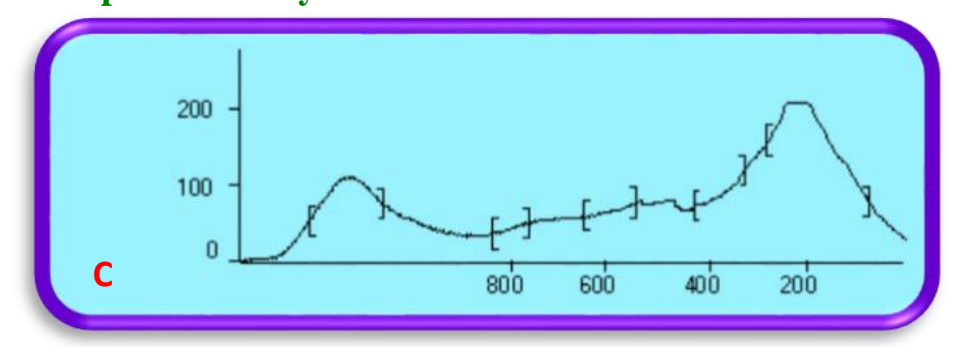

Optical density of DNA

Mol weight in bp

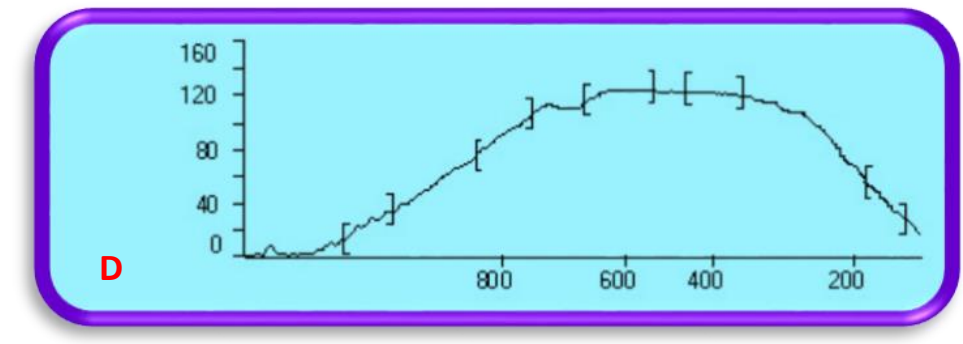

Optical density of DNA

Mol weight in bp

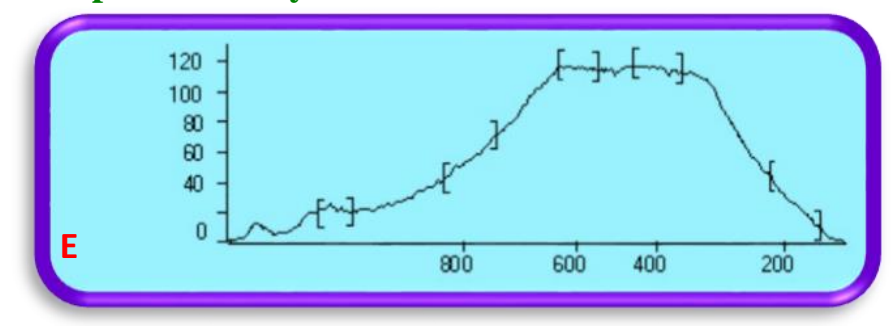

Mol weight in bp,

Figure(13): Histograms of optical density of intact and apoptic fragments of DNA at 200, 400, 600 and 800 bp in liver of mices treated with MTX before Omega, Ap and Ps. (A): Control; (B): MTX; (C):MTX before Omega; (D):MTX before Apple; (E):MTX before Psyllium. 